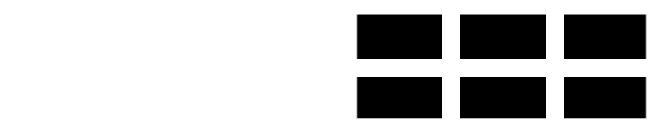

THE WILLIAM DAVIDSON INSTITUTE AT THE UNIVERSITY OF MICHIGAN BUSINESS SCHOOL

\title{
CPI Bias and Real Living Standards in Russia During the Transition
}

\author{
By: John Gibson, Steven Stillman and Trinh Le
}

William Davidson Institute Working Paper Number 684 May 2004 


\title{
CPI Bias and Real Living Standards in Russia
}

\section{During the Transition}

\author{
John Gibson \\ Department of Economics \\ University of Waikato \\ jkgibson@waikato.ac.nz
}

\author{
Steven Stillman \\ Labour Market Policy Group \\ New Zealand Dept of Labour \\ steven.stillman@1mpg.dol.govt.nz
}

\author{
Trinh Le \\ Department of Economics \\ University of Canterbury \\ Trinh.Le@canterbury.ac.nz
}

\begin{abstract}
The economies of the former Soviet Bloc experienced large declines in output during the decade of transition which began with the collapse of the Soviet Union in 1991. Yet there are many reasons to believe that measured output and official deflators provide a poor proxy for the change in real living standards in transition economies. This paper uses the Engel curve methodology recently developed by Hamilton (2001) and Costa (2001) to examine changes in real living standards in Russia during the transition period and to provide an estimate of how much the official Russian CPI has overstated consumer inflation. We also examine changes in consumer durables, home production, and subjective well-being to further evaluate changes in living standards. Our findings indicate that CPI bias has caused a substantial understatement of the growth performance of the Russian economy during the transition. Even just allowing household final consumption to be deflated with bias, we find that the level of real per capita GDP in 2001 may be understated by up to thirty percent compared with using a bias-corrected deflator. Our analysis of consumer durables, home production, and subjective well-being supports the conclusion that the decline in living standards has been substantially less than what is inferred by looking at official statistics on real output.
\end{abstract}

Acknowledgements:

We are grateful for assistance from Olga Antimonova, John Bryant, Geua Boe-Gibson, Daniel Berkowitz, and Konstantin Gluschenko and to helpful comments from Betsy Brainerd, Valery Lazarev, Tom Mroz, and seminar audiences at Canterbury, Cornell, Duke, Michigan, Williams and the Northeast Universities Development Consortium Conference.

JEL: C43, E31, O12, P36

Keywords: CPI bias, Living standards, Measurement error, Prices, Russia, Transition 


\section{I) Introduction}

The economies of the former Soviet Bloc experienced large declines in measured output during the decade of transition which began with the collapse of the Soviet Union in 1991. Based on official Goskomstat statistics, Russian real GDP per capita fell by about 24 percent between 1991 and 2001. At the nadir, in 1998, the official decline was 39 percent (Shleifer and Treisman 2003). This collapse in output has led many development agencies, Russian experts, and economists, in general, to conclude that the average Russian has experienced a massive decline in living standards since the downfall of the Soviet Union (World Bank 2002 2002a; Kolodko 2000; Klein and Pomer 2001).

Yet, as highlighted in a few recent papers re-examining Russian data, there are many reasons to believe that measured output may be a poor proxy for average living standards and might be a misleading indicator for the effects that the post-Soviet transition have had on individual well-being (Shleifer and Treisman 2003). First, output is likely to have been highly overstated during the Soviet regime as most output besides military goods consisted of low quality goods that could not even been given away in a market economy (Aslund 2001). Second, Russia's unofficial economy grew rapidly during the transition period, as can be seen by examining data on electricity consumption, which has led to a large understatement of actual output (Johnson et. al. 1997). Third, direct measures of living standards including measures of diet, weight, and stature show no apparent decline during the transition period (Stillman and Thomas 2004). Fourth, it is doubtful that the Russian CPI has been able to accurately track changes in the true cost of living, as the country has been subject to extreme price shocks, as well as fundamental changes in the economic structure during the transition period (Bessonov 1998). ${ }^{1}$ If consumers shift away from goods which have rapidly increased in price and if this is not captured by the official CPI, as evidence from other countries suggests, using the CPI to convert nominal outputs to real values will understate economic output (Boskin and Jorgenson 1997; Hausman 2003).

Our goal in this paper is to examine changes in real living standards in Russia using a methodology which is not affected by the above problems and to provide an estimate of how much the official Russian CPI has overstated consumer inflation during the transition period. Recent work by Hamilton (2001) and Costa (2001) has developed an approach for measuring

\footnotetext{
${ }^{1}$ For example, during the 1998 economic crisis, the monthly inflation rate approached 40 percent.
} 
differences between changes in real living standards and CPI-deflated nominal incomes (referred to as CPI bias) by examining changes in Engel curves over time. This method "infers" changes in real living standards from movements in the household food budget shares after controlling for changes in relative prices and demographics.

We focus on CPI bias as a particularly important factor leading to possible mis-measurement of real living standards in Russia because large prices shocks during the transition period are likely to have caused consumers to rapidly substitute between goods and because 'shock therapy' led to enormous changes in the nature of goods available to Russian households, ${ }^{2}$ to retail structure and consumer purchasing patterns, ${ }^{3}$ and to the degree of market integration. ${ }^{4}$ Moreover, the degree and speed of price liberalisation varied enormously across Russian cities, and during the early stages of the transition the national market became more fragmented rather than more integrated (Gluschenko, 2003).

We also examine changes in consumer durables, home production, and subjective wellbeing to further evaluate changes in real living standards during the transition period. While other researchers have looked at these measures from other data sources with the same goal in mind (Filer and Hanousek 2002; Shleifer and Treisman 2003), we are the first to our knowledge to integrate these measures into a framework that simultaneously examines more objective measures of living standards.

Using data from the Russian Longitudinal Monitoring Survey, we find an average CPI bias of about two percentage points per month from during 1992 and 1993 and about one percentage point per month from 1994 to 2001. The cumulative effect of this bias causes a substantial understatement of the growth performance of the Russian economy during the transition. Even just allowing household final consumption to be deflated with bias, we find that the level of real per capita GDP in 2001 may be understated by up to thirty percent compared with using a biascorrected deflator. Our analysis of durables, home production, and subjective well-being support

\footnotetext{
${ }^{2}$ The ratio of imports to GDP rose from an average of 19 percent in 1989-90 to 26 percent in 1999-2000. Moreover, the source of the imports also changed, with those sourced from the former Soviet republics (CIS countries) falling from 32 percent of the total in 1996 to 22 percent in 2002 (IMF, 2003). These changes are likely to have altered the quality of consumer goods available to the Russian population.

${ }^{3}$ For example, the number of retail stores and public catering establishments doubled, from 455,000 in 1992 to 935,000 by 1999 (Spulber, 2003, 323). While many of the new outlets were small (with fewer than 30 workers) large, foreign-owned, hyper-stores such as IKEA also entered Russia.

${ }^{4}$ For example, it was three years after prices were liberalised during the 1992 economic reforms before food prices in state-run stores resembled closely the prices in private retail outlets (Berkowitz et al., 1998).
} 
the conclusion that the decline in living standards in Russia during the transition period has been substantially less than what is inferred by looking at official statistics on real output.

\section{II) The Russian Consumer Price Index}

Each month, the Russian statistical authority (Goskomstat) collects prices on 400 representative goods and services from 350 towns and cities. ${ }^{5}$ This exercise covers every capital city of the 89 regions, with the other towns chosen by taking a representative sample of remaining urban areas. Approximately one-half of the items are industrial goods, and the remainder are split between foods and services. Rented housing is excluded from the index. If an item cannot be priced at a surveyed store, town, or region, imputation is made by substituting an appropriate item from a neighbouring store, town or region. The prices are collected from a variety of different enterprises, including state-run, municipal, and private ones, as well as from urban markets. In total, the price collection covers 30,000 retail outlets.

The monthly price changes are then aggregated for each of the 89 regions, where the weights are based on the structure of household expenditures for the region in the previous year. These expenditure estimates come from the Household Budget Survey, which surveys 49,000 households every quarter. The national monthly CPI is then calculated as a weighted average of the regional indices, where each region's weight is proportional to its population (Gluschenko, 2001). In addition to the overall CPI, indexes are also calculated for the three major groups: foods, industrial goods, and services. Despite the commodity and regional detail available, most attention is paid to the moments in the national average CPI.

The movements in the Russian CPI over the last decade are shown in Figure 1a. For the first two years after prices were liberalised (1992-93) the monthly inflation rate averaged 21 percent. Over the next two years the monthly average fell to only 9 percent and in the 1996-July 1998 period inflation seemed to be under control, with an average monthly increase of only 1.2 percent. However, the August 1998 financial crisis triggered a new bout of price rises, with the monthly inflation rate spiking at 38 percent in September 1998. In addition to increases in the overall price level, inflation in Russia has also been accompanied by a large shift in relative prices (Fig 1b). Food has become cheaper relative to non-food, especially in the early months of

\footnotetext{
${ }^{5}$ Prior to 1998, prices for only 280 goods and services were collected. See Goryacheva (1999) and Gluschenko (2001) for more details.
} 
liberalisation in 1992, from early 1995 until just after the August 1998 crisis, and again since mid 1999. The fall in the relative price of food has been driven especially by increases in the prices of services.

The Russian CPI is a Laspeyres index, which finds the cost of purchasing a fixed basket in a base period and the cost of buying the same basket in the present. Compared to the muchdebated CPI in the United States, the Russian index has several positive features, such as the large sample used to obtain the expenditure weights and the frequent updating of the weights. Nevertheless, this type of index is known to produce a number of biases, compared to the conceptual standard of a true cost of living index (Hausman, 2003). In particular, because consumers may substitute away from higher priced goods (and outlets), while a Laspeyres index continues measuring the price of the higher priced items (from the original outlets), the CPI will be an upwardly biased estimate of changes in the true cost of living. ${ }^{6}$ While this commodity substitution bias is typically thought of as contributing no more than one-fifth of the total CPI bias in developed countries, it may contribute more in transition economies where price shocks are larger. $^{7}$

Estimates of commodity substitution bias exist for Russia, and these suggest that over the 1992-96 period, the official CPI overstated the rise in prices in Russia by 35 percent (Bessonov, 1998). However, evidence on the contribution that other sources, such as outlet bias, quality change and new products make to the total bias in the Russian CPI is unavailable. It is because of the difficulty of isolating and measuring each individual source of bias that we adopt a different approach This approach, introduced by Costa (2001) and Hamilton (2001), gives reduced form estimates of the overall bias in the CPI, inferred from movements in food Engel curves over time, allowing us to correctly deflate nominal output and measure true changes in real living standards during the transition period.

\footnotetext{
${ }^{6}$ Conversely, a Paasche index based on the current basket of goods, gives an underestimate of changes in the true cost of living. The geometric average of the Laspeyres and Paasche indexes (i.e., a Fisher index) is unbiased but not practical because statistical agencies cannot update the basket of goods instantaneously.

${ }^{7}$ The Boskin Commission estimated commodity substitution bias of 0.15 percentage points out of a total annual bias of 1.1 percentage points in the U.S. This was comparable to the outlet bias of 0.1 percentage points and smaller than the formula bias of 0.25 percentage points and the bias due to quality change and new products of 0.6 percentage points. Estimates are mostly similar for other developed countries, except for the formula bias, which relates to the way that individual price quotations are aggregated. In the U.S. they are aggregated using the arithmetic average of ratios (a.k.a. the Carli index) which produces a higher average price change than does either the ratio of averages
} 


\section{III) Empirical Methodology}

Engel's Law states that food's budget share is inversely related to household real income. ${ }^{8}$ Thus, provided that the researcher can control for movements in relative prices and household characteristics, it should be possible to "infer" changes in real incomes from movements in the share of food. In other words, we are looking for 'drift' in the Engel curve, after all incomes have supposedly been put on a common temporal basis by deflating them by the CPI. Inconsistency between the trends in food budget shares and trends in real income can be attributed to changes in the relative price of food, demographic changes or to bias in the CPI (Costa 2001).

The advantage of food as an indicator good is that its low income elasticity makes its budget share sensitive to the mismeasurement of income, whereas goods with income elasticities close to one will have budget shares that are unchanged through time even if income growth is mismeasured. Food is also a non-durable, implying that expenditures in one period cannot provide a flow of consumption in another, and is likely to be separable from other goods in consumers' utility functions. ${ }^{9}$

This method can best be illustrated by considering two cross-sections of Russian household budgets, centered on November 1996 and November 1998. In the two years between these two cross-sections the official CPI rose almost 90 percent, due in large part to the August 1998 financial crisis. Consider an average household with monthly total expenditures of 1900 roubles in $1996 .^{10}$ The food budget share for this household would be 43.9 percent according to the Engel curve illustrated in Figure 2. Holding everything constant except for price level changes, this household two years later would have a real expenditure level of only 1000 roubles (in November 1996 prices). Hence, to the extent that the CPI measures the true cost-of-living for this household, it should retreat up the Engel curve to have a food budget share of 48.4 percent in 1998. In fact, households with CPI-deflated total expenditures of 1000 roubles in November

\footnotetext{
(a.k.a. the Dutot index) or the geometric mean of the price ratios (a.k.a the Jevons index). Formula bias is less important in many other developed countries, which use either the Jevons or the Dutot index (Ducharme, 1997).

${ }^{8}$ Studies have shown Engel's law to hold not only in the cross-section data where it was first observed, but in timeseries analysis as well (Houthakker 1987).

${ }^{9}$ Hamilton (2001) shows that to decompose food and non-food expenditures into a price and a quantity index requires assuming additive separability of food and non-food in consumers' utility functions and homotheticity in the subutilities of food and non-food. If these conditions are met, CPI bias in such goods as computers will not affect food's budget share through any complementarities or substitutabilities.

${ }^{10}$ Values are in terms of the new roubles, introduced from 1998, where one new rouble $=1000$ old roubles. A value of 1900 roubles would place this household at the $83^{\text {rd }}$ percentile of the expenditure distribution in 1996.
} 
1998 had food budget shares of only 44.4 percent. Thus, when viewed from the standard of their budget shares, Russian households in November 1998 acted as if they are significantly better off than their CPI-deflated income would indicate.

Hamilton (2001) and Costa (2001) take this basic idea and introduce an empirical framework that can be used to measure CPI bias from a food Engel curve estimated on different years of cross-sectional micro data. This framework covers both the case when geographic and temporal variation in food and non-food prices is available and when it is not. It starts with the Leser-Working form of the Engel curve, where the budget share is a linear function of the logarithm of real household income and a relative price term: ${ }^{11}$

$w_{i, j, t}=\phi+\gamma\left(\ln P_{F, j, t}-\ln P_{N, j, t}\right)+\beta\left(\ln Y_{i, j, t}-\ln P_{j, t}\right)+\mathbf{X}^{\prime} \theta+u_{i, j, t}$

where $w_{i, j, t}$ is the budget share of food for household $i$ in region $j$ and time period $t, P_{F, j, t}, P_{N, j, t}$, and $P_{j, t}$ represent the true but unobserved prices of food, non-food, and all goods, $Y$ is the household's total income (which is measured here by total expenditure), $\mathbf{X}$ is a vector of individual household characteristics and $u$ is the disturbance. The true cost of living is treated as a geometric weighted average of food and non-food prices:

$\ln P_{j, t}=\alpha \ln P_{F, j, t}+(1-\alpha) \ln P_{N, j, t}$

and it is assumed that prices of a good $G$ (either food, non-food, or all goods) are measured with error,

$$
\ln P_{G, j, t}=\ln P_{G, j, 0}+\ln \left(1+\Pi_{G, j, t}\right)+\ln \left(1+E_{G, t}\right) .
$$

In equation (3), $\Pi_{G, j, t}$ represents the cumulative percentage increase in the CPI-measured price of good $G$ from period 0 to period $t$ and $E_{G, t}$ is the period- $t$ percent cumulative measurement error in the cost-of-living index since the base period. By inserting equation (3) into (2), it is apparent that,

$$
\ln \left(1+E_{t}\right)=\alpha \ln \left(1+E_{F, t}\right)+(1-\alpha) \ln \left(1+E_{N, t}\right)
$$

Assuming that CPI bias does not vary geographically, inserting equations (2), (3) and (4) into equation (1) gives:

\footnotetext{
${ }^{11}$ This functional form provides the basis of the Almost Ideal Demand System of Deaton and Muellbauer (1980). Results when a quadratic in log income is used are also described below.
} 


$$
\begin{aligned}
w_{i, j, t} & =\phi+\gamma\left[\ln \left(1+\Pi_{F, j, t}\right)-\ln \left(1+\Pi_{N, j, t}\right)\right] \\
& +\beta\left[\ln Y_{i, j, t}-\ln \left(1+\Pi_{j, t}\right)\right]+\mathbf{X}^{\prime} \theta \\
& +\gamma\left[\ln \left(1+E_{F, t}\right)-\ln \left(1+E_{N, t}\right)\right]-\beta \ln \left(1+E_{t}\right) \\
& +\gamma\left(\ln P_{F, j, 0}-\ln P_{N, j, 0}\right)-\beta \ln P_{j, 0}+u_{i, j, t} .
\end{aligned}
$$

An empirical version of equation (5) can be estimated if a database can be constructed from a time-series of cross-sectional household expenditure surveys and a temporal and crosssectional CPI for food, non-food and all consumption:

$$
\begin{aligned}
w_{i, j, t} & =\hat{\phi}+\gamma\left[\ln \left(1+\Pi_{F, j, t}\right)-\ln \left(1+\Pi_{N, j, t}\right)\right] \\
& +\beta\left[\ln Y_{i, j, t}-\ln \left(1+\Pi_{j, t}\right)\right]+\mathbf{X}^{\prime} \theta \\
& +\sum_{t=1}^{T} \delta_{t} D_{t}+\sum_{j=1}^{J} \delta_{j} D_{j}+u_{i, j, t}
\end{aligned}
$$

where $D_{t}$ is a dummy variable equal to 1 in period $t, D_{j}$ is a dummy equal to 1 for region $j, \delta_{t}$ and $\delta_{j}$ are their coefficients, and $\hat{\phi}$ is the intercept from equation (5), plus the coefficients of the omitted time and region dummies. The time dummy variables are crucial to the measurement of CPI bias because

$\delta_{t}=\gamma\left[\ln \left(1+E_{F, t}\right)-\ln \left(1+E_{N, t}\right)\right]-\beta \ln \left(1+E_{t}\right)$

and if equation (7) is written in terms of the cumulative bias in the CPI for all goods, $\ln \left(1+E_{t}\right)$, and if it is assumed that the relative bias between food and non-food is constant across years, then:

$$
\ln \left(1+E_{t}\right)=\frac{\delta_{t}}{-\beta-\frac{\gamma(1-r)}{1-\alpha(1-r)}}
$$

In other words, the bias can be identified up to an unknown parameter, $r$, which is the ratio of CPI bias in food to non-food, and also depends on $\alpha$, which is food's share in the cost-of-living index. Hamilton (2001) notes that equation (8) can be reduced to:

$$
\ln \left(1+E_{t}\right) \approx \frac{-\delta_{t}}{\beta}
$$

if either $\gamma$ or $(1-r)$ is close to zero. In other words, equation (9) is likely to hold if either relative price movements are unimportant to food demand or if CPI-bias in food and non-food is equal. If instead, the price index for food is less badly biased $(r<1)$, which seems plausible due to the measurement difficulties with items like computers, then equation (9) understates the bias. Thus, 
a lower bound for cumulative percentage CPI bias at period $t$ is given by a simple ratio of estimated coefficients from equation $(6), 1-\exp \left(-\delta_{t} / \beta\right)$.

When cross-sectional variation in relative food prices is unavailable, equation (6) cannot be estimated because there is no way to identify the parameter on food prices, $\gamma \cdot{ }^{12}$ Simply using temporal movements in an aggregate price index for food relative to non-food will not work because this period-by-period variation will be perfectly correlated with the time dummy variables, $D_{t}$ so the model could not be estimated. The specification that must be used when cross-sectional variation in food prices is unavailable is:

$$
w_{i, t}=\hat{\phi}+\beta\left[\ln Y_{i, t}-\ln \left(1+\Pi_{t}\right)\right]+\mathbf{X}^{\prime} \theta+\sum_{t=1}^{T} \delta_{t} D_{t}+u_{i, t} .
$$

The dummy variables in equation (10) measure not just the CPI bias of equation (7) but also the effect on budget shares of intertemporal variation in the measured inflation rate for food relative to non-food. Hence, the cumulative percentage CPI bias at time $t$ is calculated from:

$$
1-\exp \left\{\frac{\delta_{t}-\bar{\gamma}\left[\ln \left(1+\pi_{F, t}\right)-\ln \left(1+\pi_{N, t}\right)\right]}{-\beta}\right\}
$$

where $\bar{\gamma}$ has to be obtained from outside of the estimated parameters for equation (10).

In the Russian context, regionally disaggregated data are available for the food and non-food inflation rates, so equations (6) and (9) provide the basic framework, following the approach of Hamilton (2001) of using food and non-food inflation rates rather than price levels to identify $\gamma$. However, we also use the no-regional-price variation approach described by equations (10) and (11) as a cross-check on the results.

\section{IV) Data}

To estimate equation (6) we use data from the Russian Longitudinal Monitoring Survey (RLMS), which is an on-going nationally representative longitudinal household survey designed and implemented by Barry Popkin and his colleagues at the Carolina Population Center, University of North Carolina, in collaboration with colleagues at the Russian Academy of Sciences and the Russian Institute of Nutrition. RMLS collects data on an exhaustive list of individual and household characteristics including detailed expenditure data. We also use the monthly CPI for

\footnotetext{
${ }^{12}$ Hamilton (2001) uses cross-sectional variation in inflation rates, rather than price levels, to identify $\gamma$ from data for 25 major urban areas in the U.S.
} 
food, industrial goods and services that is calculated for each of the 89 regions of Russia, and the overall CPI that is calculated nationally for the combined total of all goods and services.

RLMS has operated in two phases, each with their own samples and data collection instruments. ${ }^{13}$ The first phase operated almost continuously between July 1992 and February 1994, with four rounds of data collected from approximately 6,700 households. ${ }^{14}$ These households were located in 21 survey sites in 16 different Oblasts. ${ }^{15}$ The second phase spans the period 1994 through 2001, with six rounds of data collected from approximately 4,000 households. ${ }^{16}$ The sampling for the second phase was based on a division of Russia into 38 strata, with one primary sampling unit (PSU) chosen from each strata. Several secondary sampling units were chosen within each PSU, giving approximately 160 survey sites from more than 30 different Oblasts. Both phases are designed to be representative, however, to accommodate the changed sample, plus changes in the questionnaire, our analysis is carried out separately for each.

Two other features of the RLMS also affect the analysis. First, neither phase collected much information on the value of production for own consumption. Because it is mainly food that is self-produced, any attempt by us to value self-produced items is likely to affect the food budget share and the Engel curve estimates. This sensitivity to imputation procedures is most likely to affect rural households, so these households are excluded from the analysis. This sample restriction should not diminish the relevance of the results because the prices for the CPI are collected from towns and cities, so urban households seem to be the relevant sample. Moreover, urban households account for 77 percent of the sample and population.

Second, while RLMS is a longitudinal survey, for cost reasons, it does not attempt to follow individuals or households who move from their original sample dwelling. Instead, any new household member or new household living at the sample dwelling is included in the sample in

\footnotetext{
${ }^{13}$ A full project description is available at www.cpc.unc.edu/rlms which provides sampling procedures, survey instruments and field protocols.

${ }^{14}$ The second and subsequent survey rounds began in Dec 1992, May 1993 and October 1993. However, most interviews were conducted in August-October 1992; January-March 1993; June-July 1993; and NovemberDecember 1993.

${ }^{15}$ Russia's 89 regions are called either a republic (if it is a national autonomy), a krai (if it has a small scale national autonomy called okrug within its borders), or an oblast.

${ }^{16}$ Surveys were conducted in the late Fall of 1994, 1995, 1996, 1998, 2000, and 2001 (waves 5 through 10, respectively). Most of the interviews were done in the following months: November and December, 1994; October and November, 1995; October and November, 1996; November and December, 1998; October and November, 2000; October and November, 2001.
} 
each wave. The sample will remain representative of the underlying population assuming new entrants are exchangeable with movers. ${ }^{17}$ Since the Engel curve method for measuring CPI bias does not require the use of true panel data, and can be applied to repeated cross-sections (for example, Costa, 2001), we initially ignore the panel characteristics of the data in our analyses. But as a further check on the robustness of the results, the models are re-estimated using household fixed effects, exploiting the panel structure of the data.

\section{V) Estimation Results}

Equations (6) and (10) are estimated for a sample of two-adult families, with or without children, where the adults are between 21-75 years old. These restrictions are similar to those employed by Hamilton and Costa. The Engel curve relationship should hold for any group of people properly controlling for taste variables and thus a better estimate of CPI bias can be obtained by focusing on a fairly homogeneous group. ${ }^{18}$ Control variables include real total expenditures, relative food price changes, demographic, educational and employment characteristics, indicators of dwelling characteristics, and regional and time dummies. ${ }^{19}$ Two variants of the total expenditure variable are used; one that includes all items enumerated by the survey and one that excludes durable purchases. The model also includes the budget share for food out of the home. This form of consumption is not part of the dependent variable because it is assumed that restaurant meals are not perfect substitutes for food-at-home. Ideally, the substitution possibilities between restaurants and home cooking would be captured by including the relative price of restaurant meals but this is not available. Therefore, we follow Costa and Hamilton in using the budget share for restaurant meals as an explanatory variable, in place of the required price.

A description of the dependent and explanatory variables is contained in Appendix Table 1. To show how food shares, prices, income and household characteristics have changed over time, the beginning and end-period averages of the variables are reported in addition to the full-sample average. The dependent variable, which is the share of consumption devoted to food at home,

\footnotetext{
${ }^{17}$ See Thomas, Frankenberg, and Smith (2001) for a discussion of the likely implications of this assumption. Heeringa (1997) provides some dated information on attrition in RLMS and discusses its overall representativeness.

${ }^{18}$ In fact, this sample selection does not appear to influence the pattern of results, as shown by the robustness tests in Appendix Table 2.

${ }^{19}$ We previously included dummies for the gender and ethnic minority status of the household head but these variables always had small and statistically insignificant coefficients. The indicator for separate dwellings is not included in the model for Phase I because details about the dwelling are not available from Round 3 of the survey.
} 
averages 58 percent in phase I and 54 percent in Phase II. ${ }^{20}$ The average food share fell by 2 percentage points between Rounds 1 and 4 in Phase I and by 9 percentage points between Rounds 5 (late 1994) and 10 (late 2001) of Phase II, despite declines in CPI-deflated total consumption in both phases. Similar patterns are shown in the panel sub-sample from Phase II. This sub-sample excludes the new households who moved into sample dwellings, so by Round 10 it is older and has slightly lower expenditures and a higher food share.

The estimation is carried out using both OLS and Instrumental Variables, because of concerns about measurement error in the total expenditures variable. Measurement error bias in the total expenditures coefficient, $\beta$ would flow through into the estimate of CPI-bias (see equation 9). Household income is used as an instrument because this variable is collected independently of the total expenditures variable.

Phase I results

Table 1 contains the results of estimating equation (10) with the Phase I RLMS data. No attempt is made to estimate the more general equation (6) that uses regional relative food prices because for Phase I we lack the geographical identifiers needed to match the regional CPIs to the primary sampling units of the survey. The negative coefficient on deflated total consumption indicates that food budget shares fall as households become richer, which is precisely why food is used as the indicator good here. This fall is most apparent in the IV results, which are the preferred ones because the Hausman test indicates some inconsistency in the OLS estimates.

Relative to the base period (July-Oct, 1992), the food share is about two percentage points lower in Round 2 and three points lower in Round 4 (Nov-Dec, 1993), conditional on the other covariates. But in contrast to the expected pattern with CPI-bias, the food share in Round 3 (June-July, 1993) is higher than in the base period. Seasonality is a possible culprit for this pattern, because the Household Budget Survey also shows higher average food shares in the June quarter than in any other quarter.

Seasonality interferes with the measurement of CPI bias, but to the extent that Round 1 and Round 4 have some overlapping months, a tentative estimate can be made. Combining the three percentage point fall in the conditional food budget share from Round 1 to Round 4 with movement in the national food-non-food inflation rate (using an estimate of $\bar{\gamma}=0.19$ which is derived using an approach described below), the application of equation (11) suggests a

\footnotetext{
${ }^{20}$ These two averages are not comparable because of differences in the samples and the questionnaires.
} 
cumulative CPI bias of approximately 0.33 between July 1992 and the end of $1993 .^{21}$ This implies an average monthly bias of about 2 percentage points per month, during a period when the average monthly change in the CPI was about 20 percentage points. This estimate should not be regarded as definitive because of the short time period for Phase I of the RLMS and the imperfect synchronisation of the survey rounds in the same period each year. These problems are much less apparent in Phase II.

\section{Phase II results}

Table 2 contains the estimates of the food Engel curves for the phase II data. The key result is that relative to the base period (Nov-Dec, 1994), the food share is $1,4,8,10$, and 11 percentage points lower in the subsequent survey rounds, conditional on the other covariates. All of these changes, except for the fall in the food share from Round 5 to Round 6 are statistically significant. Thus, there has been continual downward drift in the food Engel curve, a specific example of which was illustrated in Figure 2 for 1996 and 1998. By comparing the four columns of regression results, it is clear that this drift in the food Engel curve is not affected very much by either the particular definition of household expenditures or the estimation method. In contrast to Phase I, there is no significant difference between the IV and OLS results.

Several sensitivity analyses are reported in Appendix Table 2. The first is the national-level model, where regional effects and the regional variation in relative food prices is excluded (equation (10)). Some analysts might favour this model because the relative food price effect is not very precisely estimated in Table 2 . Regardless, the pattern of the period dummy variables is very similar to what was previously estimated, although these now measure not just CPI bias but also the effect on budget shares of intertemporal variation in the measured national inflation rate for food relative to non-food. The other checks include augmenting the model with a quadratic expenditure term, ignoring the sampling weights, including all households, dropping extreme values of food budget shares, ${ }^{22}$ and removing households with low (and possibly mis-measured)

\footnotetext{
${ }^{21}$ If the OLS estimates are used, the cumulative bias is between 0.56 and 0.64 , with the higher figure from the estimates that exclude durables purchases.

${ }^{22} \mathrm{We}$ trim the sample to include only those households with food shares in the $0.02-0.90$ interval. This is a deeper cut than made by Hamilton (2001) who excluded households if their food share exceeded 80 percent, which is over four times higher than the mean food share in his sample. In contrast, the 90 percent threshold used here is less than twice the mean food share.
} 
levels of expenditures. ${ }^{23}$ All specifications point to the same result; there is an unexplained decline in the food budget share of between 10 and 13 percentage points between 1994 and 2001.

The panel structure of the data is exploited in Table 3, which contains the results of including household fixed effects in the regressions. Compared with the cross-sectional results, the dummy variables for most time periods are somewhat larger in absolute value, so the introduction of the fixed effects acts to slightly raise the CPI bias estimates. This similarity of the results in Table 3 with those from Table 2 also gives an indirect indication of the lack of sensitivity of the bias estimates to sample attrition. ${ }^{24}$

\section{VI) Discussion}

The estimation results indicate a persistent and substantial downward drift in the food Engel curves. We attribute this drift to unmeasured growth in real expenditures. We have no reason to believe that the nominal expenditure estimates from the RLMS are becoming increasingly understated, so in turn, this mis-measurement of real expenditures is attributed to CPI bias. If the assumptions underlying equation (9) are satisfied, the cumulative CPI bias after each round of the RLMS is found by dividing the coefficient on the dummy variable for the round by the income coefficient: $1-\exp \left(-\delta_{t} / \beta\right)$. The average monthly bias can be found by dividing the difference between cumulative bias estimates by the number of months separating them.

Over the seven years from November 1994 to November 2001, the cumulative bias in the Russian CPI is estimated to lie somewhere between 0.64 and 0.87 , depending on the estimation method, sample, and expenditure definition used (Table 4). This range corresponds to an average monthly bias of between 0.8 and 1.0 percentage points. The lower values come from the IV estimates but only one of the four Hausman tests was statistically significant, so there is no strong reason for favouring these lower values. Amongst the OLS results, the most precise measure of bias comes from the cross-sectional estimate of a cumulative bias of 0.80 , with $\hat{\sigma}=0.04$, when durable purchases are excluded from the expenditure definition. Thus, our preferred estimate of the average monthly bias is 0.9 percentage points, which compares with a

\footnotetext{
${ }^{23}$ Here defined as less than 600 roubles per month.

${ }^{24}$ The sample for the fixed effects estimates is restricted to the households from Round 5 that were present in subsequent rounds (6120 household-round observations versus 7753 observations when the new households who moved into sample dwellings are included).
} 
monthly CPI inflation rate of 3.2 percentage points over 1994-2001. In other words, almost one third of the measured rise in the cost of living can be attributed to CPI bias.

The level of CPI bias appears to be falling, both absolutely and relative to the inflation rate. Between Rounds 5 and 8 (late 1994 to late 1998) the average bias was 1.5 percentage points per month, while the monthly inflation rate was 4.2 percentage points. ${ }^{25}$ But between Rounds 8 and 10 (late 1998 to late 2001) the average bias was just 0.3 points per month, with a monthly inflation rate of 1.9 percentage points. This fall in the bias seems plausible because it is earlier in the period where there was the greatest volatility in prices, which would contribute to commodity substitution bias. It was also in the immediate aftermath of price liberalisation when prices between state-run and private stores diverged the most, giving more scope for outlet bias if the price surveys by Goskomstat failed to keep pace with changing consumer shopping patterns. Improvements made by Goskomstat in 1998, which included an extension from 280 to 400 items in the basket, also are likely to have contributed to a reduction in the bias.

One concern with the results in Table 4 is that the substantial change in relative food prices illustrated in Figure $1 \mathrm{~b}$ is controlled for only imprecisely because the food price coefficient, $\gamma$ in Tables 2 and 3 are surrounded by wide standard errors. So as a sensitivity analysis, a value for $\gamma$ is also derived from an equation with no price data (this equation is reported in the first column of Appendix Table 2). ${ }^{26}$ Equation (11) is then used to combine this derived estimate, $\bar{\gamma}$ with information on the aggregate movement in the relative price of food in order to retrieve estimates of CPI bias from the coefficients of a model without regional effects and without relative food prices. The cumulative bias estimates ranged from 0.70 to 0.76 , and were only 0.04 points below the estimates from the model with food prices included. Thus, we doubt that uncertainty about the size of $\gamma$ greatly affects the results. In terms of the other sensitivity analyses in Appendix Table 2, the cumulative bias estimates for Round 10 range from $0.64-0.75$, with a mean value of 0.70. Once again, this is quite close to the preferred values reported in Table 4.

\footnotetext{
${ }^{25}$ This monthly average of 1.5 points lends some credence to our earlier estimate, from the RLMS Phase I data, of a two percentage point monthly bias between July 1992 and the end of 1993.

${ }^{26}$ The specific steps were to first use the method proposed by Frisch (1959) to get an own-price elasticity from the food budget share, $w_{i}$ the income elasticity of food demand, $\eta$ and the 'flexibility of money' $e_{i i}=(1 / \omega) \eta_{i}\left(1-w_{i} \eta_{i}\right)-w_{i} \eta_{i}$, where $\omega$ is -4.2 , based on the relationship used by Lluch et. al. (1977) of $\omega \approx-36 X^{-0.36}$, where $X$ is GNP per capita in 1970 U.S. dollars, which we estimate to between $\$ 300$ and $\$ 700$ for Russia over the 1992-2001 period. The resulting value for $e_{i i}$ of -0.56 was then used to derive an estimate of $\gamma=0.19$, noting that for equation (1), the ownprice elasticity is: $e_{i i}=-1+(\gamma-\alpha \beta) / w$ where $\alpha$ is the share of food in the overall price index.
} 
What are the implications of this CPI bias for assessments of the trend in living standards during Russia's transition to a market economy? Figure 3 displays the trend in real per capita GDP, which shows the 'usual' story that GDP in 2001 was only three-quarters of its 1991 value. ${ }^{27}$ To the extent that GDP statistics measure welfare, this suggests that transition was associated with a precipitous drop in the Russian population's standard of living. But if the value of real Household Final Consumption Expenditure is adjusted for the effect of CPI bias, a rather different picture emerges. Just adjusting consumption, and leaving all other components unchanged, real per capita GDP would be 20 percent higher in 2001 if it is assumed that there was no CPI bias prior to 1994 (that is, just using the Engel curve results from Phase II of RLMS). Allowing for bias back to 1992, by also using the results from Phase I of RLMS, real per capita GDP in 2001 is 30 percent higher than its officially reported level, and has returned to the level experienced in 1991.

\section{VII) Additional Evidence}

Our results suggest that the official inflation figures considerably overstate rises in the cost of living in Russia and contribute to an overly pessimistic view of declining living standards during the transition. Some corroborating evidence for these conclusions comes from data in two other parts of the RLMS questionnaires. The first concerns the ownership of durable goods, while the second uses subjective questions on changes in economic welfare.

Increasing ownership rates for consumer durables are not consistent with the prolonged decline in real household consumption that is indicated by the official statistics. According to the RLMS figures, the proportion of urban households owning a VCR rose steadily from only 20 percent in 1994 to 53 percent in 2001. Less dramatic but equally steady rises in ownership rates are indicated for color TVs, and cars and trucks (Figure 4). Yet between 1994 and 1998, the official figures suggest that real per capita GDP fell by 11 percent. There is a high income elasticity of durables ownership, so this falling real GDP seems inconsistent with the improvements in living standards indicated by rising ownership rates for household durables. ${ }^{28}$

\footnotetext{
27 The estimates are in local currency units, series NY.GDP.MKTP.KN from the World Development Indicators.

${ }^{28}$ In cross-sections for the first (1994) and last (2001) years in the sample, unit increases in log household expenditures are associated with 26 percentage point and 28 percentage point increases in the probability of the household owning a VCR. These values come from an IV estimation of a linear probability model.
} 
Self-reported changes in economic welfare in Russia are also more consistent with the biasadjusted CPI than with the official CPI. In Round 9 (2000) the RLMS asked: 'How did you and your family live five years ago compared to how you live now?' and respondents were able to answer using a 5-point scale that ranged from 'lived much better', through 'lived the same as now' to 'lived much worse'. Time series of similar questions have been used by Nordhaus (1998) and Krueger and Siskind (1998) to measure CPI bias in the U.S., while Filer and Hanousek (2002) use a cross-section of similar data to measure CPI bias in Romania. The idea is to look for the deflator that gives the closest association between the subjective, self-rated welfare change, and an objective measure of welfare change based on deflated per capita expenditures.

When the official CPI is used to deflate per capita expenditures, a majority (59 percent) of those who rated themselves as being better off in 2000 than in 1995 are in the group for whom the CPI indicates a fall in real per capita expenditures (Table 5a). Similarly, the group who indicated no change in their living standards are divided 63:37 between those with apparent falls in CPI-deflated expenditure and those with rises. When the bias-adjusted CPI is used to deflate per capita expenditures, a (slight) majority of those who indicate that they were better off in 2000 also have a rise in the objective welfare measure, while the 55:45 split for those indicating "no change' is closer to the 50:50 split that would be expected (Table 5b). In terms of statistical significance, two measures of association for categorical data - Cramer's $V$ and the chi-squared statistic - indicate significantly better fit $(p=0.04)$ between the objective and subjective welfare changes when the bias-adjusted CPI is used. Taking the comparisons in Table 5 one step further, a grid search was carried out to find the CPI that best reconciles the subjective report of welfare change with the objective change in deflated per capita total expenditures. Both Cramer's $V$ and the chi-squared statistic are maximized by a CPI that equals 379 in $2000(1995=100)$. This is rather closer to the value of the bias-adjusted CPI than it is to the official CPI (Figure 5).

One concern with our estimates of CPI bias is that the observed downward trend in food budget shares may be caused by increases in own-production of food by urban households, the so-called 'Dacha production' and not by increases in real living standards as we are assuming. To check this possibility, RLMS data on consumption from self-produced potatoes are evaluated, as potatoes are the main food grown by urban households. The available evidence does not suggest any bias in our previous estimates (Table 6). First, between 1995 and 2001 there been a 
continuous decline in the proportion of urban households consuming self-produced potatoes. Second, when consumption values are imputed from the reported quantities (using the median unit value for potato purchases), and compared to the total value of consumption, the apparent budget share for self-produced potatoes has fallen by two-thirds. Finally, augmenting the food budget share to include self-produced potatoes has no effect on the level or pattern of cumulative CPI bias.

Another concern relates to how much faith can be placed on the results for an Engel curve that is estimated over a period that includes a major economic crisis (the August 1998 financial crisis). McKenzie (2001) has shown that after the 1994 Mexican Peso crisis, budget shares for food staples increased by more than a pre-crisis food Engel curve would predict. In contrast, shares for non-staple foods and semi-durables like clothing fell by more than the Engel curve would predict. However, such adjustments are less apparent amongst Russian households (Table 7). Whilst there was a small rise in the budget share for staple food in 1998, which was accommodated by a fall in the non-staple food share, there was no reduction in the budget shares for semi-durables. ${ }^{29}$ Moreover, if we simply remove all observations from 1998 (Round 8) from our sample, and re-estimate CPI bias, the cumulative bias estimates by 2001 are exactly the same as those reported previously in Table 4.

\section{VIII) Conclusions}

In this paper we estimate Engel curves for the food budget share of Russian households, based on data from the Russian Longitudinal Monitoring Survey. These estimates are then used to infer the extent that the official Russian CPI has overstated the rise in the cost of living and hence understated real income growth during the transition period. We find an average CPI bias of about two percentage points per month during 1992 and 1993 and about one percentage point per month from 1994 to 2001 . The cumulative effect of this bias causes a substantial understatement of the growth performance of the Russian economy during the transition. Even just allowing household final consumption to be deflated with bias, while assuming that the deflators for the other components of GDP are unbiased, we find that the level of real per capita GDP in 2001 may be understated by up to thirty percent compared with using a bias-corrected deflator. 
Combined with other adjustments, such as for growth in the unofficial economy and the reduction in wasteful production (Shleifer and Treisman, 2003), the real value of GDP may in fact be rather larger than it was at the beginning of transition. Even the official figures show that household consumption collapsed less than investment and government spending, so after correction for CPI-bias, a rise in average household living standards during the transition seems highly likely. Our analysis of durables, home production, and subjective well-being also support the conclusion that the decline in real living standards in Russia during the transition period has been substantially less than what is inferred by looking at official statistics on real output.

A large literature attempts to explain the divergent experiences of various transition countries, as a function of differences in initial conditions, political change and the intensity of reform (de Melo, et al, 2001; Falcetti, et al., 2002). In this literature, Russia is seen as one of the 'failures' in transition. It is unlikely that the degree of CPI bias that we find for Russia occurs in all other transition countries. Thus, part of the gap in performance that these studies attempt to explain may in fact not exist. For example, the Czech Republic is usually considered as a successful transition, with output declining for only three years and by only 12 percent (World Bank, 2002). In contrast to the case for Russia, it is unlikely that correcting for CPI bias would change these figures because existing studies find only modest price index biases in the Czech Republic (Brada, et al, 2000). ${ }^{30}$

These results also contribute a solution to the puzzle raised by Stillman and Thomas (2004) about the contrast between the stability of nutritional indicators and the size of the shock to real incomes in 1998. While the 1998 crisis still shows up in the bias-adjusted data, as an 8 percent deviation from the trend in per capita GDP, it is preceded by some years of growth, rather than the decline that is apparent in the official data. Thus, it is less surprising that households were able to cope with the 1998 shock and buffer their nutrition than it would have been if they had exhausted their resources in dealing with the previous seven year decline in living standards that the official data indicate.

\footnotetext{
${ }^{29}$ There are 16 items included as staples: white bread, black bread, macaroni products, rice/cereals, cabbage, potatoes, beets/carrots, onions/garlic, vegetable oil, flour, salt/spices, tea, milk, margarine and sugar. These were identified based on their low expenditure elasticity of demand, in both rounds 5 and 10.

${ }^{30}$ Filer and Hanousek (2000) offer a different interpretation. However, the debate on the bias in deflators for the Czech Republic has not been informed by the sort of detailed empirical work presented here. This large difference in the severity of CPI bias should not be surprising as Russia experienced an annual inflation rate during transition of 2,500 percent compared to only 52 percent in the Czech Republic.
} 


\section{References}

Aslund, A. 2001. "The Myth of Output Collapse After Communism" Working Paper No. 18, Carnegie Endowment for International Peace, Washington DC.

Berkowitz, D., DeJong, D., and Husted, S. 1998. "Quantifying Price Liberalization in Russia" Journal of Comparative Economics 26(4): 735-760.

Bessonov, V. 1998. "On Biases in Evaluations of Rise in Russian Consumer Prices" Economical Journal of the High School of Economics 2(2): 31-38.

Boskin, M. and Jorgenson, D. 1997. "Implications of Overstating Inflation for Indexing Government Programs and Understanding Economic Progress" American Economic Review 87(2):89-93.

Brada, J., King, A. and Kutan, A. 2000. "Inflation Bias And Productivity Shocks in Transition Economies: The Case of the Czech Republic" Economic Systems 24(2): 119-138.

Costa, D. 2001. "Estimating Real Income in the United States from 1888 to 1994: Correcting CPI Bias Using Engel Curves” Journal of Political Economy 109(6): 1288-1310.

Deaton, A., and Muellbauer, J. 1980 “An Almost Ideal Demand System" American Economic Review 70(3): 312-326.

de Melo, M., Denizer, C., Gelb, A., and Tenev, S. 2001. "Circumstances and Choice: The Role of Initial Conditions and Policies in Transition Economies" World Bank Economic Review 15(1): 1-31.

Ducharme, L. 1997. Bias in the CPI; Experiences from Five OECD Countries. Ottawa: Statistics Canada.

Falcetti, E., Raiser, M., and Sanfey, P. 2002. "Defying the Odds: Initial Conditions, Reforms and Growth in the First Decade of Transition" Journal of Comparative Economics 30(2): $229-250$.

Filer, R., and Hanousek, J. 2000. "Output Changes and Inflationary Bias in Transition" Economic Systems 24(3): 285-294.

Filer, R., and Hanousek, J. 2002. "Survey-based Estimates of Biases in Consumer Price Indices During Transition: Evidence from Romania” Journal of Comparative Economics 30(3): 476-487.

Frisch, R. 1959. "A Complete System for Computing all Direct and Cross Demand Elasticities in a Model with Many Sectors" Econometrica 27(2): 177-196. 
Gluschenko, K. 2001. "Biases in the Russian Regional CPIs" mimeo Institute of Economics and Industrial Engineering, Siberian Branch of the Russian Academy of Sciences

Gluschenko, K. 2003. "Market Integration in Russia During the Transformation Years" Economics of Transition 11(3): 411-434.

Goryacheva, I. 1999. "Methodology for Measuring Inflation in the Russian Federation” Joint ECE/ILO Meeting on Consumer Price Indices, Geneva, 3-5 November.

Hamilton, B. 2001. "Using Engel's Law to Estimate CPI Bias" American Economic Review 91(3): 619-630

Hausman, J. 2003. "Sources of Bias and Solutions to Bias in the Consumer Price Index" Journal of Economic Perspectives 17(1): 23-44.

Heeringa, S. 1997. "Russia Longitudinal Monitoring Survey Sample Attrition, Replenishment, and Weighting: Rounds V-VII." University of Michigan Institute for Social Research (March).

Houthakker, H. 1987. “Engel's Law” in J. Eatwell, M. Milgate and P. Newman (eds.) The New Palgrave Dictionary of Economics. Vol. 2 (London: McMillan), pp. 143-144.

International Monetary Fund. 2003. "Russian Federation: Statistical Appendix" IMF Country Report No. 03/145, May 2003.

Johnson, Simon, Daniel Kaufmann, and Andrei Shleifer. 1997. "The Unofficial Economy in Transition.” Brookings Papers on Economic Activity 2: 159-221.

Klein, Lawrence R. and Marshall Pomer. 2001. The New Russia: Transition Gone Awry. Stanford, CA: Stanford University Press.

Kolodko, Grzegorz W. 2000. From Shock to Therapy: The Political Economy of Postsocialist Transformation. World Institute for Development Economics Research of the United Nations University. Oxford: Oxford University Press.

Krueger, A. and Siskind, A. 1998. "Using survey data to assess bias in the Consumer Price Index" Monthly Labor Review 121(4): 25-33.

Lluch, C., Powell, A., and Williams, R. 1977. Patterns in Household Demand and Saving, Oxford: Oxford University Press for the World Bank.

McKenzie, D. 2001. "The consumer response to the Mexican Peso crisis" Northeast Universities Development Consortium Conference, Boston University.

Nordhaus, W. 1998. "Quality changes in price indexes" Journal of Economic Perspectives 12(1): 59-68. 
Shleifer, A., and Treisman, D. 2003. "A normal country” Working Paper 10057, National Bureau of Economic Research.

Spulber, N. 2003. Russia's Economic Transitions: From Late Tsarism to the New Millennium Cambridge: Cambridge University Press.

Stillman, S., and Thomas, D. 2004. "The Effect of Economic Crises on Nutritional Status: Evidence from Russia" mimeo

Thomas, D., Frankenberg, E. and Smith, J. 2001. "Lost but Not Forgotten: Attrition and Follow-up in the Indonesia Family Life Survey." Journal of Human Resources 36(3): 556-92.

World Bank. 2002. Transition - the First Ten Years: Analysis and Lessons for Eastern Europe and the Former Soviet Union Washington: The World Bank.

World Bank. 2002a. "Poverty in Russia" Country Assistance Strategy of the World Bank Group for the Russian Federation (Report No. 24127-RU) Attachment 3, pp. 43-45. 
Figure 1a: Russian Monthly CPI Inflation Rate: 1992-2003

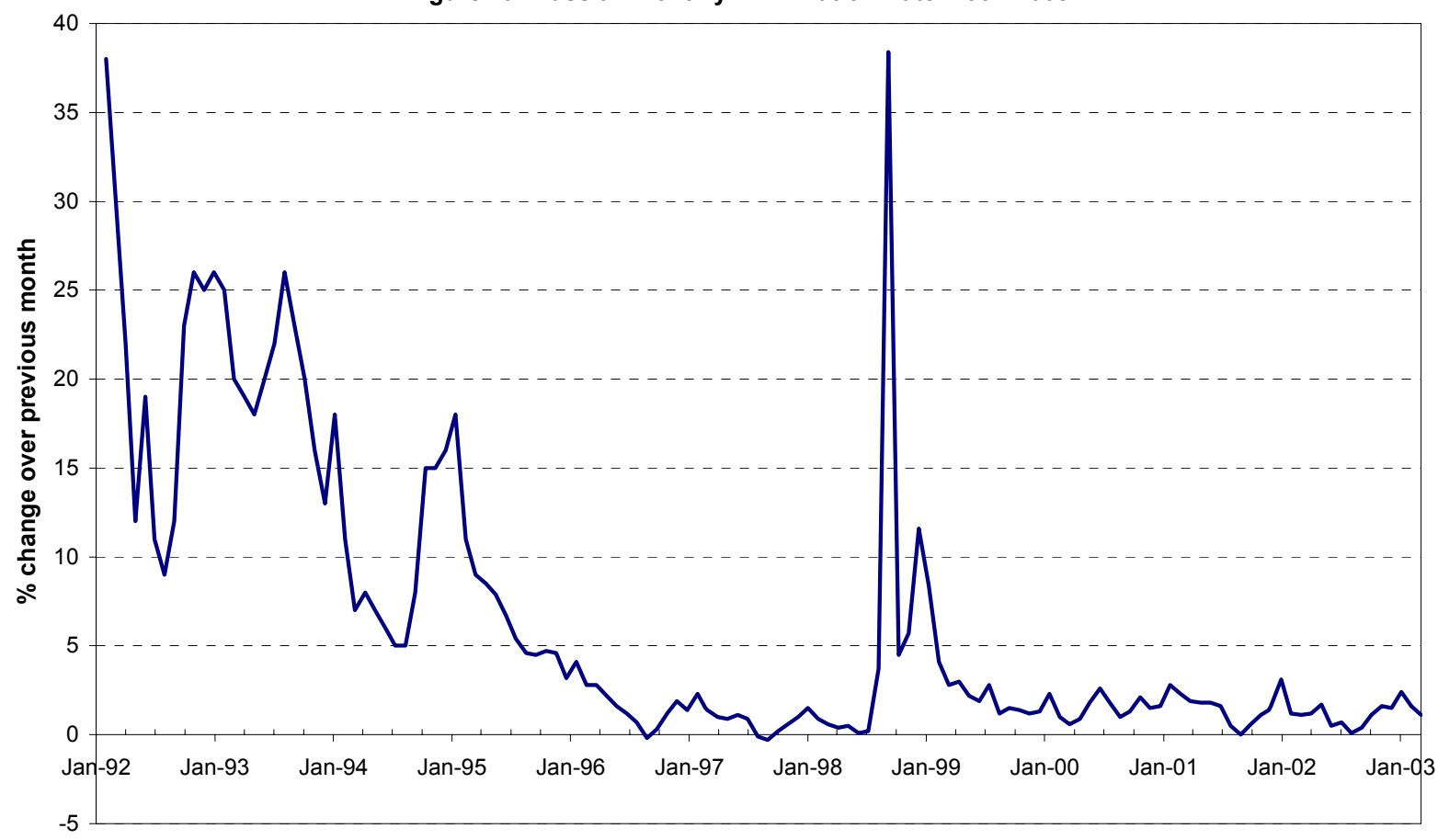

Figure 1b. Relative Food/Non-Food Price Changes in Russia: 1992-2003

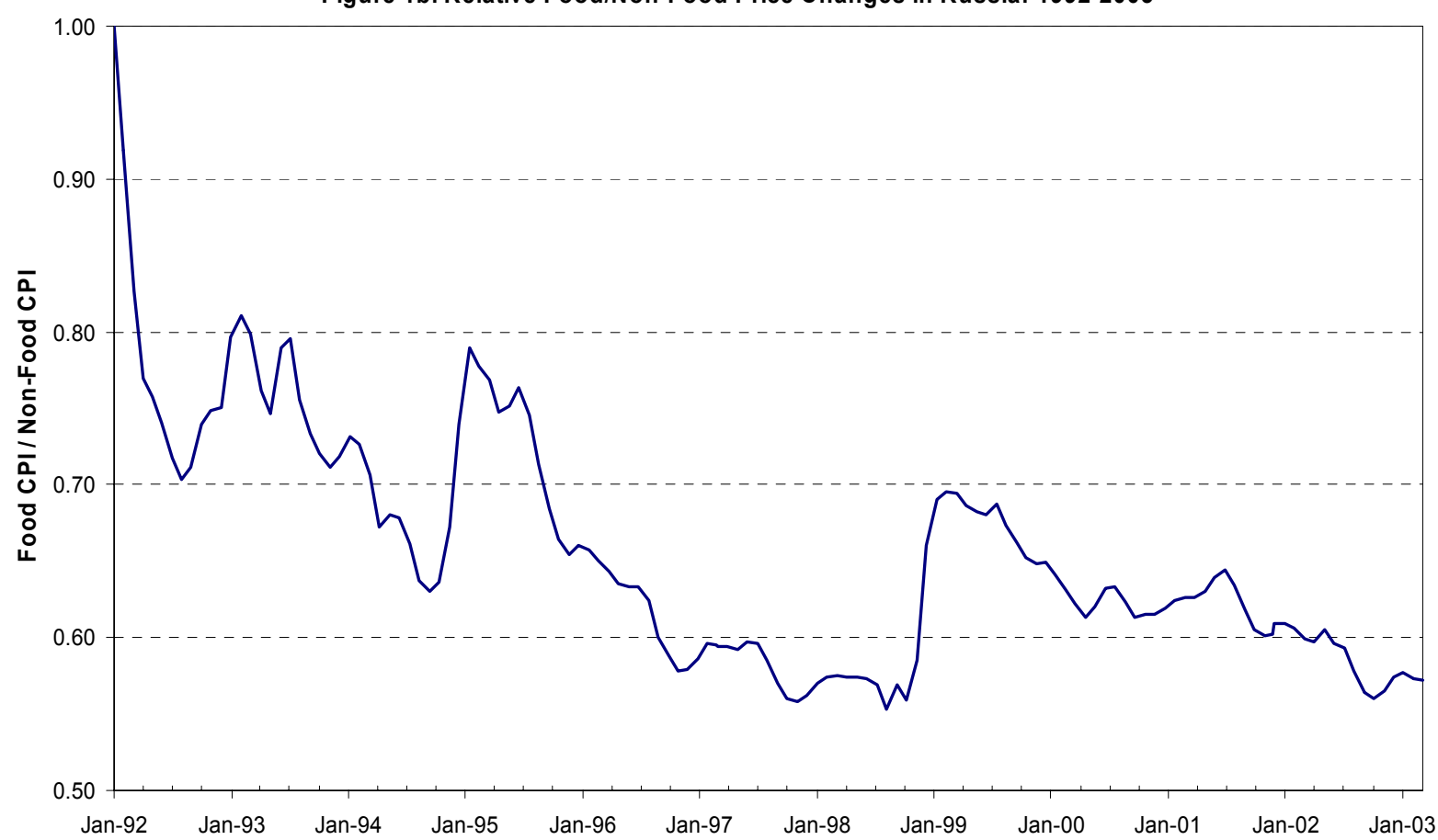


Figure 2: Food Engel Curves for 1996 and 1998

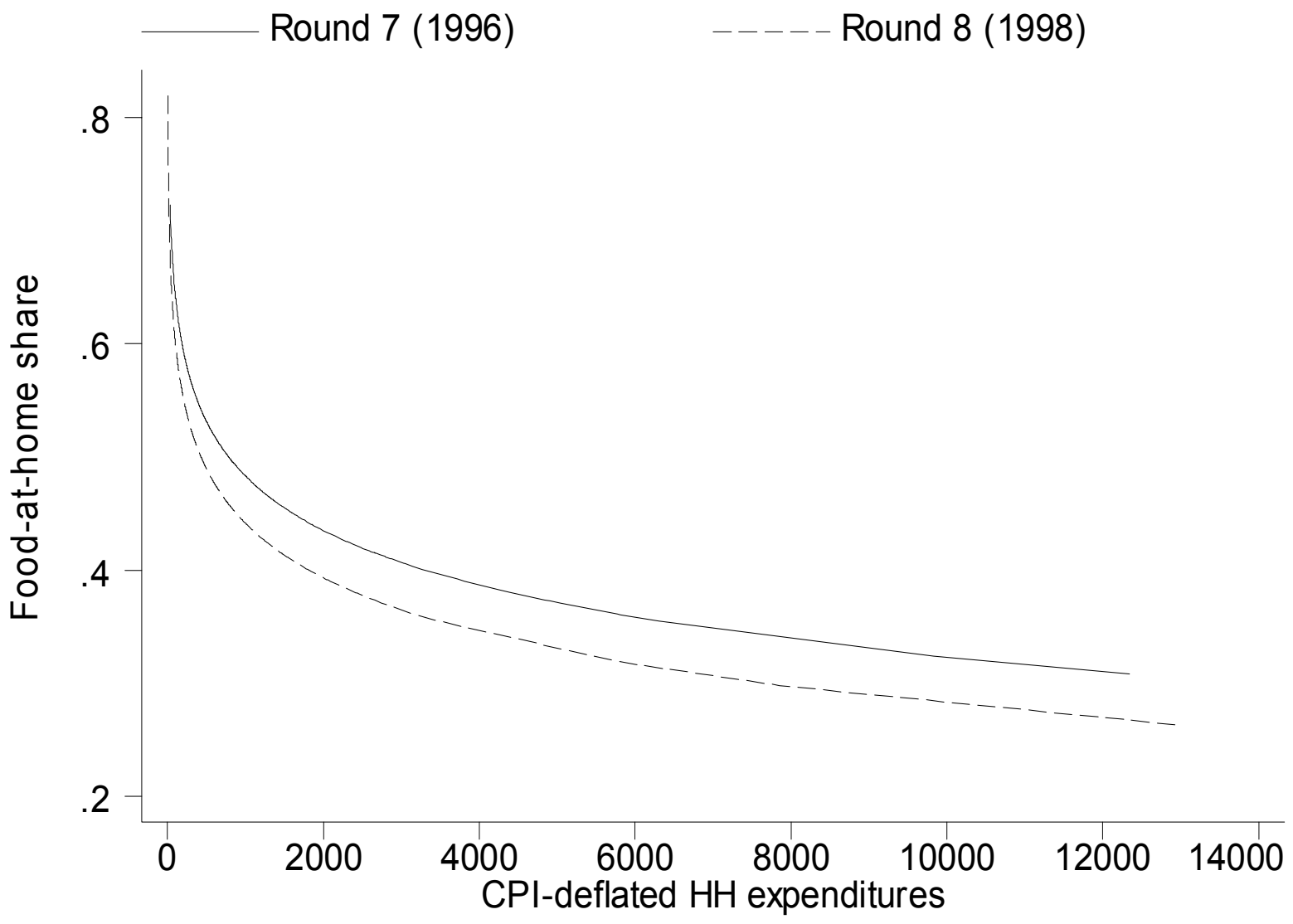


Figure 3: Effect of CPI Bias on Estimates of Real per capita GDP in Russia

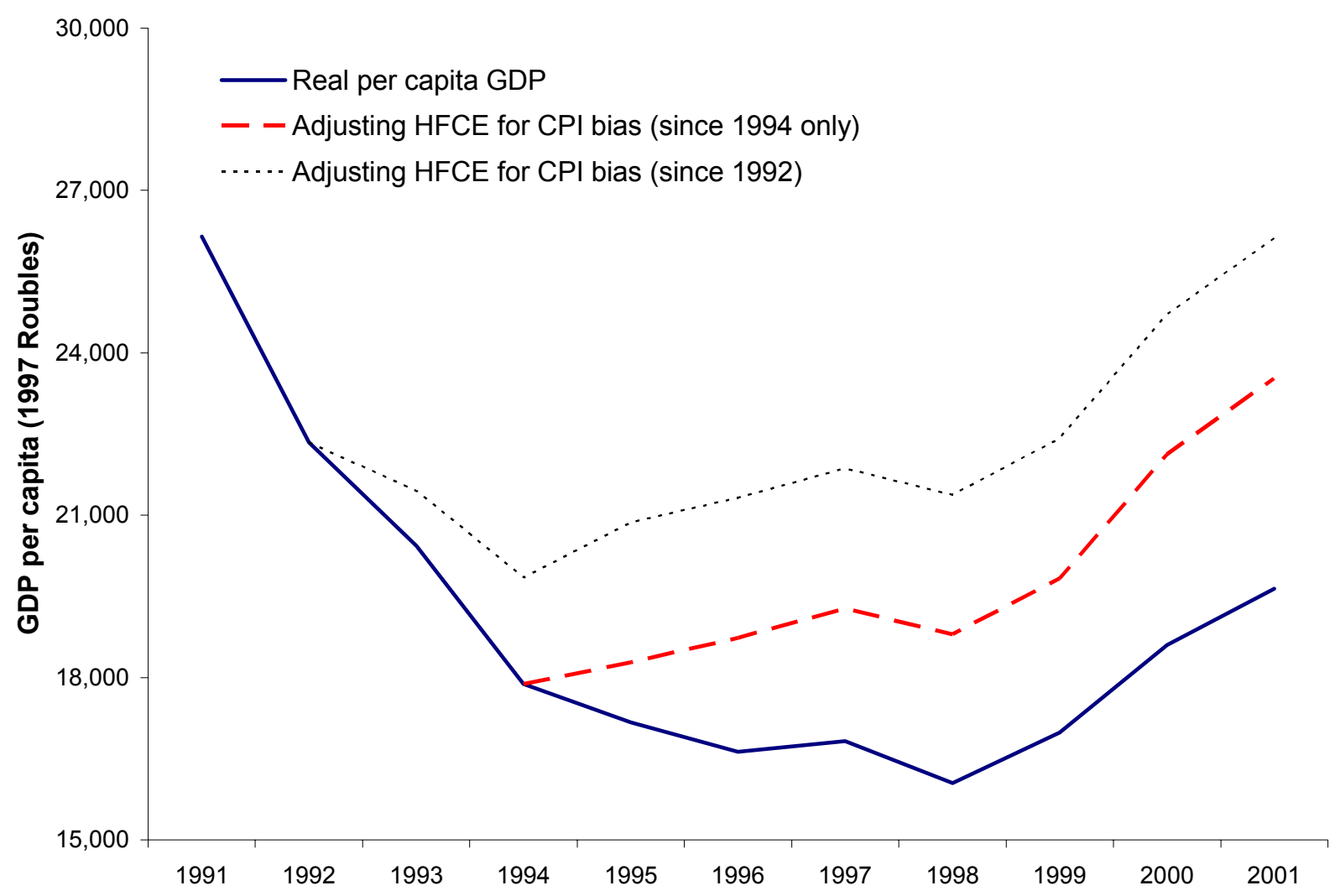

Note: $\mathrm{HFCE}=$ Household Final Consumption Expenditure 
Figure 4: Ownership Rate for Certain Household Durables (urban, 2-adult families)

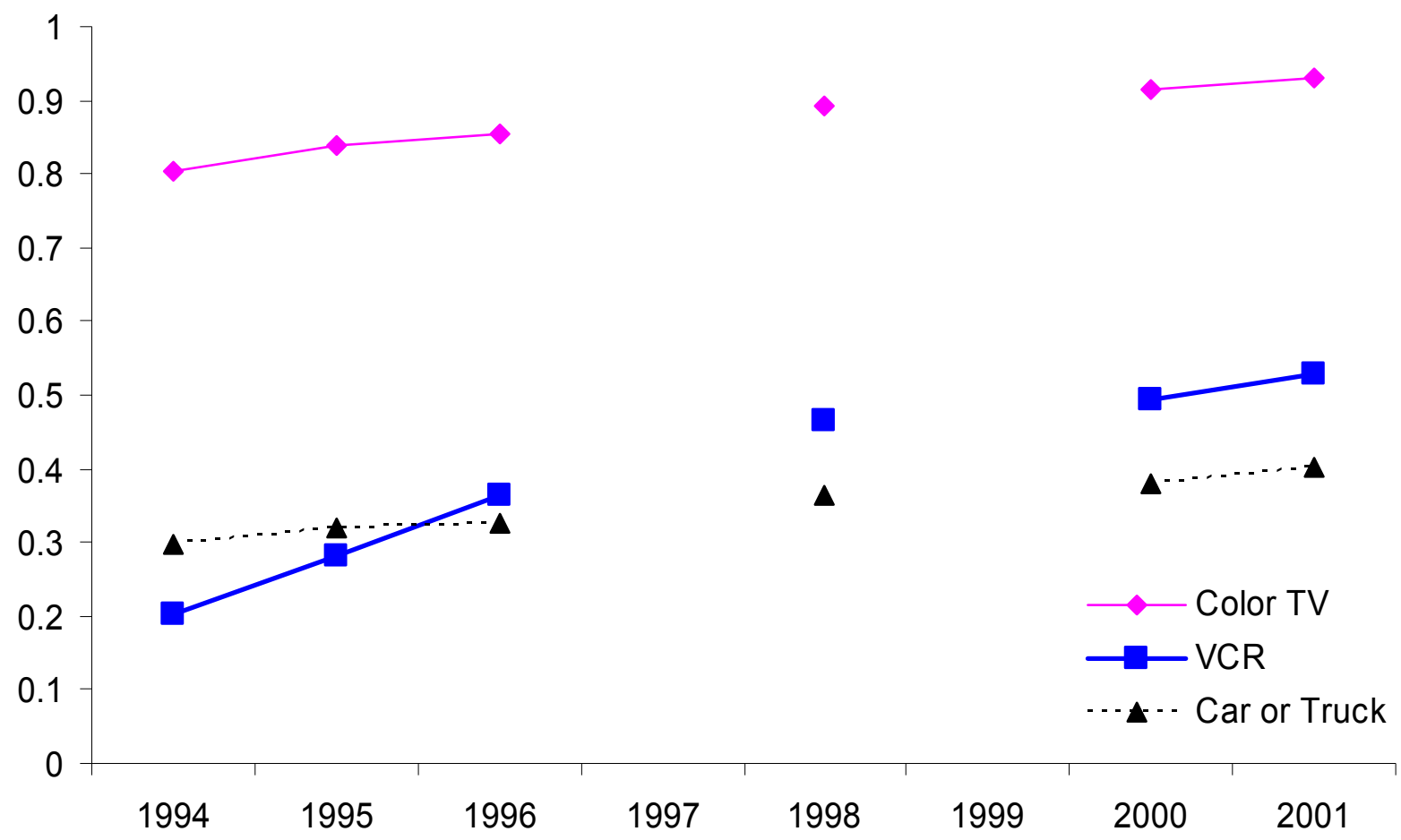


Figure 5: Grid Search Results for Russian Consumer Price Inflation

Rate That Reconciles Objective and Subjective Welfare Changes

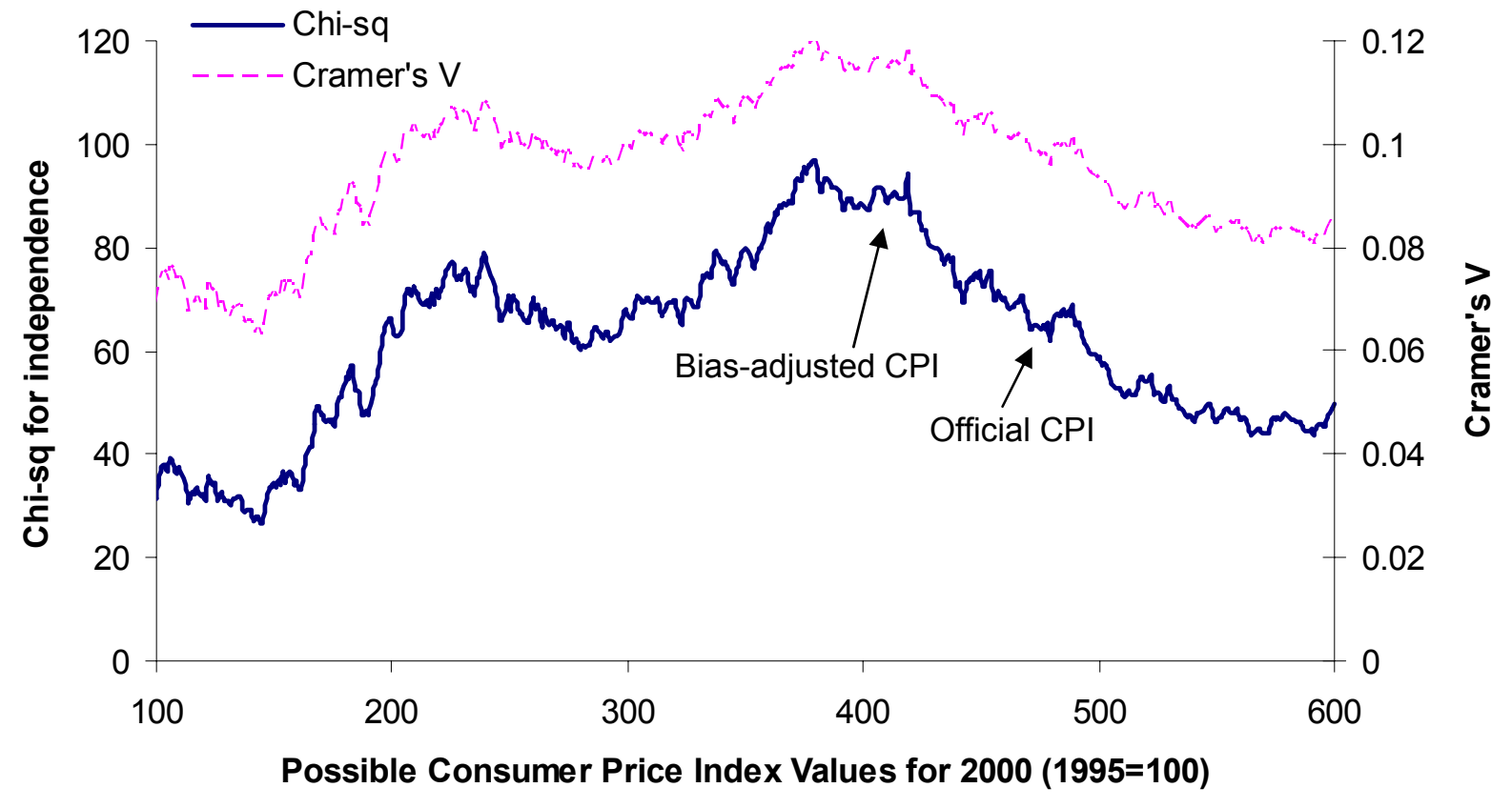


Table 1: Food Engel Curve Estimated from Phase I RLMS

\begin{tabular}{|c|c|c|c|c|}
\hline & \multicolumn{2}{|c|}{$\underline{\text { OLS Estimates }}$} & \multicolumn{2}{|c|}{ IV Estimates $^{\mathrm{a}}$} \\
\hline & $\begin{array}{c}\text { All } \\
\text { expenditures }\end{array}$ & $\begin{array}{c}\text { Excluding } \\
\text { durables }\end{array}$ & $\begin{array}{c}\text { All } \\
\text { expenditures }\end{array}$ & $\begin{array}{c}\text { Excluding } \\
\text { durables }\end{array}$ \\
\hline ln (real total expenditure) & $\begin{array}{l}-0.045 \\
(5.25)^{* *}\end{array}$ & $\begin{array}{l}-0.038 \\
(4.55)^{* *}\end{array}$ & $\begin{array}{l}-0.112 \\
(6.56)^{* *}\end{array}$ & $\begin{array}{l}-0.099 \\
(5.60)^{* *}\end{array}$ \\
\hline ln (household size) & $\begin{array}{l}-0.032 \\
(1.64)\end{array}$ & $\begin{array}{l}-0.040 \\
(2.09)+\end{array}$ & $\begin{array}{l}-0.001 \\
(0.04)\end{array}$ & $\begin{array}{l}-0.011 \\
(0.47)\end{array}$ \\
\hline$\%$ of household $\leq 2$ years old & $\begin{array}{c}0.134 \\
(2.16)^{*}\end{array}$ & $\begin{array}{c}0.173 \\
(2.87)^{*}\end{array}$ & $\begin{array}{c}0.049 \\
(0.70)\end{array}$ & $\begin{array}{c}0.092 \\
(1.32)\end{array}$ \\
\hline$\%$ of HH 3-14 year old boys & $\begin{array}{l}0.170 \\
(5.85)^{* *}\end{array}$ & $\begin{array}{l}0.181 \\
(6.53)^{* *}\end{array}$ & $\begin{array}{l}0.127 \\
(4.05)^{* *}\end{array}$ & $\begin{array}{l}0.142 \\
(4.60)^{* *}\end{array}$ \\
\hline$\%$ of $\mathrm{HH} 3-14$ year old girls & $\begin{array}{l}0.159 \\
(4.80)^{* *}\end{array}$ & $\begin{array}{l}0.167 \\
(5.43)^{* *}\end{array}$ & $\begin{array}{l}0.125 \\
(3.50)^{* *}\end{array}$ & $\begin{array}{c}0.136 \\
(4.00)^{* *}\end{array}$ \\
\hline$\%$ of HH $15-17$ year old boys & $\begin{array}{l}0.112 \\
(3.58)^{* *}\end{array}$ & $\begin{array}{l}0.123 \\
(3.78)^{* *}\end{array}$ & $\begin{array}{l}0.099 \\
(3.47)^{* *}\end{array}$ & $\begin{array}{c}0.111 \\
(3.71)^{* *}\end{array}$ \\
\hline$\%$ of $\mathrm{HH} 15-17$ year old girls & $\begin{array}{c}0.042 \\
(1.26)\end{array}$ & $\begin{array}{c}0.055 \\
(1.55)\end{array}$ & $\begin{array}{c}0.037 \\
(1.14)\end{array}$ & $\begin{array}{c}0.049 \\
(1.43)\end{array}$ \\
\hline Age of household head & $\begin{array}{c}0.003 \\
(3.76)^{* *}\end{array}$ & $\begin{array}{l}0.002 \\
(3.17)^{* *}\end{array}$ & $\begin{array}{c}0.003 \\
(3.59)^{* *}\end{array}$ & $\begin{array}{l}0.003 \\
(3.17)^{* *}\end{array}$ \\
\hline Age of spouse & $\begin{array}{l}0.003 \\
(3.05)^{* *}\end{array}$ & $\begin{array}{l}0.003 \\
(3.40)^{* *}\end{array}$ & $\begin{array}{c}0.002 \\
(1.83)+\end{array}$ & $\begin{array}{c}0.002 \\
(2.25)^{*}\end{array}$ \\
\hline Head has tertiary education & $\begin{array}{l}-0.003 \\
(0.60)\end{array}$ & $\begin{array}{l}-0.005 \\
(0.89)\end{array}$ & $\begin{array}{c}0.007 \\
(1.19)\end{array}$ & $\begin{array}{c}0.005 \\
(0.85)\end{array}$ \\
\hline Spouse has tertiary education & $\begin{array}{l}-0.015 \\
(2.74)^{*}\end{array}$ & $\begin{array}{l}-0.013 \\
(2.65)^{*}\end{array}$ & $\begin{array}{l}-0.008 \\
(1.33)\end{array}$ & $\begin{array}{l}-0.007 \\
(1.40)\end{array}$ \\
\hline Head is working & $\begin{array}{l}-0.007 \\
(0.96)\end{array}$ & $\begin{array}{l}-0.004 \\
(0.55)\end{array}$ & $\begin{array}{r}0.001 \\
(0.12)\end{array}$ & $\begin{array}{c}0.003 \\
(0.34)\end{array}$ \\
\hline Spouse is working & $\begin{array}{c}0.004 \\
(0.45)\end{array}$ & $\begin{array}{c}0.004 \\
(0.43)\end{array}$ & $\begin{array}{c}0.011 \\
(1.28)\end{array}$ & $\begin{array}{c}0.010 \\
(1.15)\end{array}$ \\
\hline$\%$ of budget on food out of home & $\begin{array}{l}-0.427 \\
(7.73)^{* *}\end{array}$ & $\begin{array}{l}-0.453 \\
(8.78)^{* *}\end{array}$ & $\begin{array}{l}-0.443 \\
(7.20)^{* *}\end{array}$ & $\begin{array}{l}-0.463 \\
(8.25)^{* *}\end{array}$ \\
\hline Round 2 (Jan-Mar, 1993) & $\begin{array}{l}-0.015 \\
(1.31)\end{array}$ & $\begin{array}{l}-0.021 \\
(1.86)+\end{array}$ & $\begin{array}{l}-0.018 \\
(1.57)\end{array}$ & $\begin{array}{l}-0.023 \\
(2.02)+\end{array}$ \\
\hline Round 3 (June-July, 1993) & $\begin{array}{c}0.019 \\
(2.38)^{*}\end{array}$ & $\begin{array}{c}0.015 \\
(1.83)+\end{array}$ & $\begin{array}{c}0.024 \\
(2.79)^{*}\end{array}$ & $\begin{array}{c}0.020 \\
(2.32)^{*}\end{array}$ \\
\hline Round 4 (Oct 1993-Jan 1994) & $\begin{array}{l}-0.031 \\
(3.72)^{* *}\end{array}$ & $\begin{array}{l}-0.032 \\
(3.93)^{* *}\end{array}$ & $\begin{array}{l}-0.031 \\
(3.34)^{* *}\end{array}$ & $\begin{array}{l}-0.033 \\
(3.46)^{* *}\end{array}$ \\
\hline Constant & $\begin{array}{c}0.772 \\
(9.03)^{* *}\end{array}$ & $\begin{array}{c}0.737 \\
(8.99)^{* *}\end{array}$ & $\begin{array}{c}1.378 \\
(8.69)^{* *}\end{array}$ & $\begin{array}{c}1.281 \\
(7.97)^{* *}\end{array}$ \\
\hline$R^{2}$ & 0.130 & 0.117 & 0.075 & 0.071 \\
\hline$F$-test (time dummies $=0$ ) & $11.76^{* *}$ & $13.11 * *$ & $14.74 * *$ & $15.70 * *$ \\
\hline$F$-test (instrument $=0$ in first stag & ression) & & $183.1 * *$ & $167.4 * *$ \\
\hline$F$-test (Hausman test for consister & f OLS) & & $28.07 * *$ & $18.87 * *$ \\
\hline $\begin{array}{l}\text { Note: Absolute value of t-statistics in pare } \\
\text { at } 5 \% \text {; ** significant at } 1 \% \text {. } N=8416 \text {. The } \\
\text { The various expenditure definitions affect } \\
\text { away-from-home share. }\end{array}$ & $\begin{array}{l}\text { es corrected for clu } \\
\text { Ided time dummy i } \\
\text { ependent variable ( }\end{array}$ & $\begin{array}{l}\text { ts but not st } \\
\text { nd } 1 \text { (Jul-Or } \\
\text { ome budget }\end{array}$ & $\begin{array}{l}\text { significant at } 10 \\
\text { (real total expen }\end{array}$ & $\begin{array}{l}\text { ignificant } \\
\text { and food- }\end{array}$ \\
\hline
\end{tabular}


Table 2: Food Engel Curve Estimated from Phase II RLMS

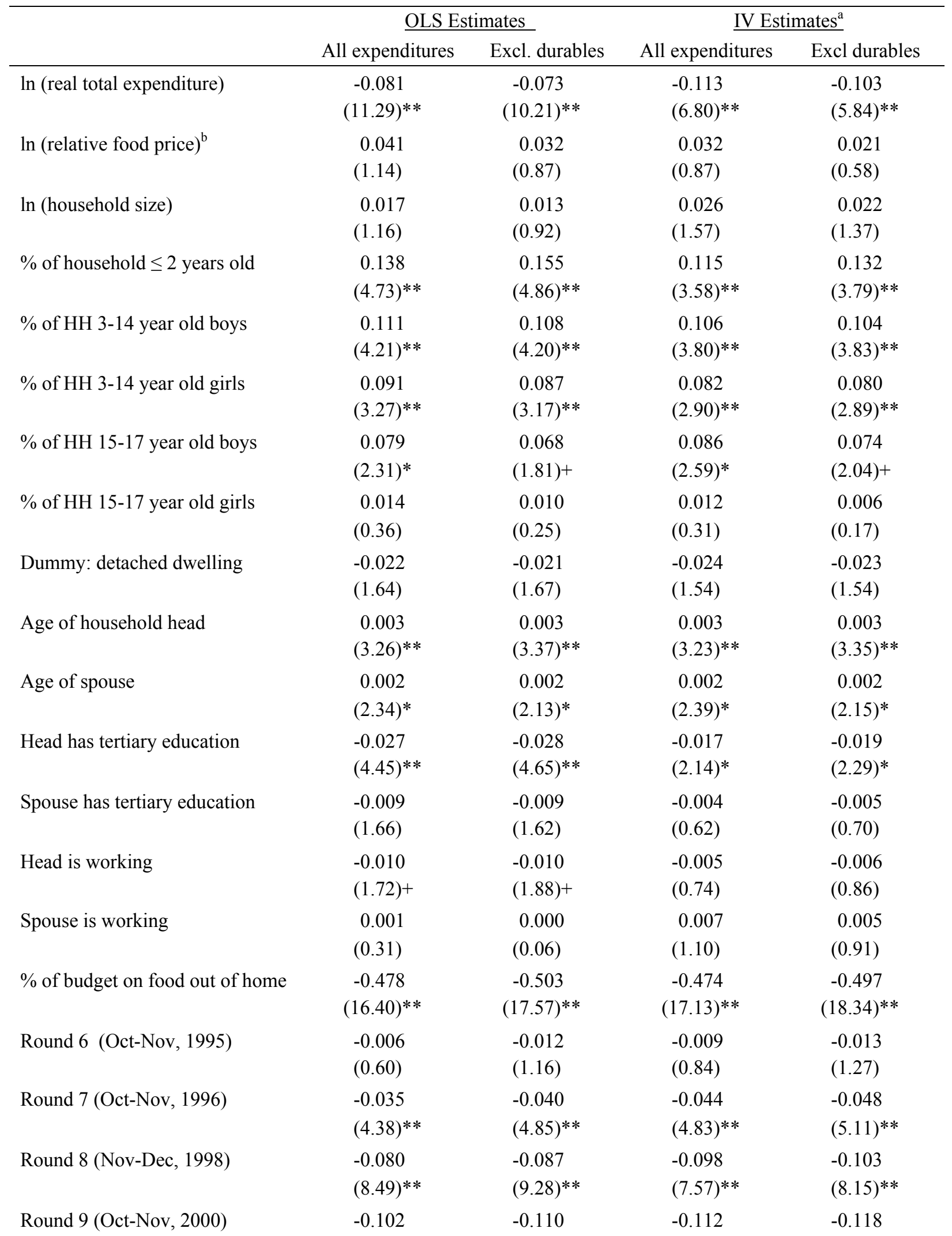




\begin{tabular}{|c|c|c|c|c|}
\hline & $(11.02)^{* *}$ & $(11.51)^{* *}$ & $(12.57)^{* *}$ & $(12.92)^{* *}$ \\
\hline Round 10 (Oct-Nov, 2001) & $\begin{array}{c}-0.108 \\
(13.05)^{* *}\end{array}$ & $\begin{array}{c}-0.115 \\
(14.94)^{* *}\end{array}$ & $\begin{array}{c}-0.115 \\
(15.62)^{* *}\end{array}$ & $\begin{array}{c}-0.120 \\
(17.56)^{* *}\end{array}$ \\
\hline Constant & $\begin{array}{c}1.388 \\
(16.58)^{* *}\end{array}$ & $\begin{array}{c}1.311 \\
(15.59)^{* *}\end{array}$ & $\begin{array}{c}1.799 \\
(8.79)^{* *}\end{array}$ & $\begin{array}{c}1.697 \\
(7.78)^{* *}\end{array}$ \\
\hline$R^{2}$ & 0.267 & 0.254 & 0.258 & 0.246 \\
\hline$F$-test (time dummies $=0$ ) & $46.2 * *$ & $59.9 * *$ & $70.4 * *$ & $87.9 * *$ \\
\hline$F$-test (region dummies $=0$ ) & $16715^{* *}$ & $17702 * *$ & $78332 * *$ & $63482 * *$ \\
\hline \multicolumn{3}{|c|}{$F$-test (instrument $=0$ in first stage regression) } & $57.8 * *$ & $58.1 * *$ \\
\hline \multicolumn{3}{|c|}{$F$-test (Hausman test for consistency of OLS) } & 2.59 & 2.29 \\
\hline \multicolumn{5}{|c|}{$\begin{array}{l}\text { Note: Absolute value of t-statistics in parentheses corrected for cluster effects but not stratification; * significant at } 5 \% ; * * \text { significant at } 1 \% \text {; } \\
+ \text { significant at } 10 \% \text {. } N=7753 \text {. The excluded time dummy is for Round } 5 \text { (Nov-Dec, } 1994 \text { ). Each equation also includes } 25 \text { regional fixed } \\
\text { effects. } \\
\text { The various expenditure definitions affect the dependent variable (food-at-home budget share), and } \ln \text { (real total expenditure) and food-away- } \\
\text { from-home share. } \\
\text { a } \ln \text { (real total expenditure) is treated as the endogenous variable, with } \ln (\text { real total household income) as the instrument. } \\
{ }^{b} \text { In terms of inflation rates rather than price levels. }\end{array}$} \\
\hline
\end{tabular}


Table 3: Food Engel Curve With Households Fixed Effects, Phase II RLMS

\begin{tabular}{|c|c|c|c|c|}
\hline & \multicolumn{2}{|c|}{$\underline{\text { OLS Estimates }}$} & \multicolumn{2}{|c|}{$\underline{\text { IV Estimates }}^{\mathrm{a}}$} \\
\hline & All expenditures & Excl. durables & All expenditures & Excl durables \\
\hline ln (real total expenditure) & $\begin{array}{c}-0.073 \\
(15.58)^{* *}\end{array}$ & $\begin{array}{c}-0.062 \\
(13.21)^{* *}\end{array}$ & $\begin{array}{l}-0.128 \\
(4.58)^{* *}\end{array}$ & $\begin{array}{l}-0.109 \\
(3.70)^{* *}\end{array}$ \\
\hline $\ln {\text { (relative food price })^{b}}^{b}$ & $\begin{array}{c}0.049 \\
(1.35)\end{array}$ & $\begin{array}{c}0.027 \\
(0.77)\end{array}$ & $\begin{array}{c}0.046 \\
(1.22)\end{array}$ & $\begin{array}{c}0.025 \\
(0.69)\end{array}$ \\
\hline In (household size) & $\begin{array}{l}-0.005 \\
(0.18)\end{array}$ & $\begin{array}{l}-0.003 \\
(0.11)\end{array}$ & $\begin{array}{c}0.018 \\
(0.60)\end{array}$ & $\begin{array}{c}0.014 \\
(0.46)\end{array}$ \\
\hline$\%$ of household $\leq 2$ years old & $\begin{array}{l}0.194 \\
(2.84)^{* *}\end{array}$ & $\begin{array}{l}0.182 \\
(2.70)^{* *}\end{array}$ & $\begin{array}{c}0.141 \\
(1.89)+\end{array}$ & $\begin{array}{c}0.140 \\
(1.92)^{+}\end{array}$ \\
\hline$\%$ of $\mathrm{HH} 3-14$ year old boys & $\begin{array}{c}0.084 \\
(1.56)\end{array}$ & $\begin{array}{c}0.073 \\
(1.37)\end{array}$ & $\begin{array}{c}0.071 \\
(1.29)\end{array}$ & $\begin{array}{c}0.061 \\
(1.13)\end{array}$ \\
\hline$\%$ of HH 3-14 year old girls & $\begin{array}{c}0.193 \\
(3.56)^{* *}\end{array}$ & $\begin{array}{c}0.175 \\
(3.27)^{* *}\end{array}$ & $\begin{array}{l}0.169 \\
(2.95)^{* *}\end{array}$ & $\begin{array}{l}0.159 \\
(2.84)^{* *}\end{array}$ \\
\hline$\%$ of HH $15-17$ year old boys & $\begin{array}{c}0.058 \\
(1.13)\end{array}$ & $\begin{array}{c}0.041 \\
(0.81)\end{array}$ & $\begin{array}{c}0.060 \\
(1.15)\end{array}$ & $\begin{array}{c}0.042 \\
(0.82)\end{array}$ \\
\hline$\%$ of $\mathrm{HH} 15-17$ year old girls & $\begin{array}{c}0.187 \\
(3.64)^{* *}\end{array}$ & $\begin{array}{c}0.180 \\
(3.55)^{* *}\end{array}$ & $\begin{array}{c}0.186 \\
(3.50)^{* *}\end{array}$ & $\begin{array}{c}0.181 \\
(3.45)^{* *}\end{array}$ \\
\hline Dummy: detached dwelling & $\begin{array}{l}-0.009 \\
(0.37)\end{array}$ & $\begin{array}{l}-0.012 \\
(0.47)\end{array}$ & $\begin{array}{c}0.001 \\
(0.05)\end{array}$ & $\begin{array}{l}-0.002 \\
(0.07)\end{array}$ \\
\hline Age of household head & $\begin{array}{c}0.005 \\
(1.36)\end{array}$ & $\begin{array}{c}0.004 \\
(1.24)\end{array}$ & $\begin{array}{c}0.006 \\
(1.74)+\end{array}$ & $\begin{array}{c}0.006 \\
(1.70)+\end{array}$ \\
\hline Age of spouse & $\begin{array}{c}0.001 \\
(0.23)\end{array}$ & $\begin{array}{c}0.000 \\
(0.12)\end{array}$ & $\begin{array}{c}0.001 \\
(0.45)\end{array}$ & $\begin{array}{c}0.001 \\
(0.41)\end{array}$ \\
\hline Head has tertiary education & $\begin{array}{l}-0.009 \\
(0.56)\end{array}$ & $\begin{array}{l}-0.010 \\
(0.63)\end{array}$ & $\begin{array}{l}-0.002 \\
(0.13)\end{array}$ & $\begin{array}{l}-0.004 \\
(0.23)\end{array}$ \\
\hline Spouse has tertiary education & $\begin{array}{c}0.011 \\
(0.75)\end{array}$ & $\begin{array}{c}0.007 \\
(0.50)\end{array}$ & $\begin{array}{c}0.017 \\
(1.08)\end{array}$ & $\begin{array}{c}0.013 \\
(0.88)\end{array}$ \\
\hline Head is working & $\begin{array}{l}-0.012 \\
(1.37)\end{array}$ & $\begin{array}{l}-0.015 \\
(1.69)+\end{array}$ & $\begin{array}{l}-0.008 \\
(0.80)\end{array}$ & $\begin{array}{l}-0.011 \\
(1.14)\end{array}$ \\
\hline Spouse is working & $\begin{array}{c}0.003 \\
(0.31)\end{array}$ & $\begin{array}{c}0.002 \\
(0.21)\end{array}$ & $\begin{array}{c}0.006 \\
(0.64)\end{array}$ & $\begin{array}{c}0.004 \\
(0.46)\end{array}$ \\
\hline$\%$ of budget on food out of home & $\begin{array}{c}-0.496 \\
(14.22)^{* *}\end{array}$ & $\begin{array}{c}-0.517 \\
(15.21)^{* *}\end{array}$ & $\begin{array}{c}-0.489 \\
(13.67)^{* *}\end{array}$ & $\begin{array}{c}-0.510 \\
(14.54)^{* *}\end{array}$ \\
\hline Round 6 (Oct-Nov, 1995) & $\begin{array}{l}-0.003 \\
(0.33)\end{array}$ & $\begin{array}{l}-0.008 \\
(0.96)\end{array}$ & $\begin{array}{l}-0.012 \\
(1.21)\end{array}$ & $\begin{array}{l}-0.015 \\
(1.60)\end{array}$ \\
\hline Round 7 (Oct-Nov, 1996) & $\begin{array}{l}-0.038 \\
(2.81)^{* *}\end{array}$ & $\begin{array}{l}-0.045 \\
(3.33)^{* *}\end{array}$ & $\begin{array}{l}-0.057 \\
(3.62)^{* *}\end{array}$ & $\begin{array}{l}-0.061 \\
(3.97)^{* *}\end{array}$ \\
\hline Round 8 (Nov-Dec, 1998) & $\begin{array}{l}-0.093 \\
(4.01)^{* *}\end{array}$ & $\begin{array}{l}-0.099 \\
(4.33)^{* *}\end{array}$ & $\begin{array}{l}-0.138 \\
(4.45)^{* *}\end{array}$ & $\begin{array}{l}-0.139 \\
(4.53)^{* *}\end{array}$ \\
\hline Round 9 (Oct-Nov, 2000) & $\begin{array}{l}-0.104 \\
(3.18)^{* *}\end{array}$ & $\begin{array}{l}-0.112 \\
(3.45)^{* *}\end{array}$ & $\begin{array}{l}-0.139 \\
(3.82)^{* *}\end{array}$ & $\begin{array}{l}-0.144 \\
(4.03)^{* *}\end{array}$ \\
\hline Round 10 (Oct-Nov, 2001) & $\begin{array}{l}-0.119 \\
(3.11)^{* *}\end{array}$ & $\begin{array}{l}-0.125 \\
(3.32)^{* *}\end{array}$ & $\begin{array}{l}-0.148 \\
(3.65)^{* *}\end{array}$ & $\begin{array}{l}-0.153 \\
(3.85)^{* *}\end{array}$ \\
\hline Constant & $\begin{array}{c}1.283 \\
(5.28)^{* *}\end{array}$ & $\begin{array}{l}1.199 \\
(4.99)^{* *}\end{array}$ & $\begin{array}{l}1.868 \\
(4.66)^{* *}\end{array}$ & $\begin{array}{l}1.670 \\
(4.05)^{* *}\end{array}$ \\
\hline$R^{2}$ & 0.223 & 0.210 & 0.220 & 0.205 \\
\hline$F$-test (time dummies $=0)^{\mathrm{c}}$ & $5.50 * *$ & $5.76^{* *}$ & $5.50 * *$ & $5.16 * *$ \\
\hline
\end{tabular}




\begin{tabular}{|c|c|c|c|}
\hline$F$-test $\left(\mathrm{H}^{\prime} \text { hold fixed effects }=0\right)^{\mathrm{c}}$ & $1.86^{* *}$ & $1.79 * *$ & $1.82 * *$ \\
\hline$F$-test (instrument $=0$ in first stage regression) ${ }^{\mathrm{c}}$ & & $131.5^{* *}$ & $117.4^{* *}$ \\
\hline$F$-test (Hausman test for consistency of OLS) ${ }^{\mathrm{c}}$ & & $3.89 *$ & 2.57 \\
\hline
\end{tabular}

Note: Absolute value of heteroscedastically robust t-statistics in parentheses; * significant at $5 \%$; ** significant at $1 \%$; + significant at $10 \%$. The sample is 1774 households who were surveyed in Round 5, with 6120 observations on those households. The excluded time dummy is for Round 5 (Nov-Dec, 1994). Each equation also includes 1773 household-level fixed effects.

The various expenditure definitions affect the dependent variable (food-at-home budget share), and ln (real total expenditure) and food-awayfrom-home share.

${ }^{a} \ln$ (real total expenditure) is treated as the endogenous variable, with $\ln ($ real total household income) as the instrument.

${ }^{\mathrm{b}}$ In terms of inflation rates rather than price levels.

${ }^{\mathrm{c}}$ The $F$-tests have numerator degrees of freedom of 5 for the test of the time dummies, 1773 for the fixed effects, and 1 for the first stage instrument and Hausman test. The denominator degrees of freedom are 4325. 
Table 4. Estimates of Cumulative CPI Bias in Russia, 1994-2001

\begin{tabular}{|c|c|c|c|c|c|c|c|c|}
\hline & \multicolumn{4}{|c|}{ Cross-Sectional Estimates } & \multicolumn{4}{|c|}{ Panel Fixed Effects Estimates } \\
\hline & \multicolumn{2}{|c|}{$\underline{\text { OLS Estimates }}$} & \multicolumn{2}{|c|}{$\underline{\text { IV Estimates }}$} & \multicolumn{2}{|c|}{$\underline{\text { OLS Estimates }}$} & \multicolumn{2}{|c|}{ IV Estimates } \\
\hline & $\begin{array}{c}\text { All } \\
\text { expenditures }\end{array}$ & $\begin{array}{l}\text { Excluding } \\
\text { durables }\end{array}$ & $\begin{array}{c}\text { All } \\
\text { expenditures }\end{array}$ & $\begin{array}{c}\text { Excluding } \\
\text { durables }\end{array}$ & $\begin{array}{c}\text { All } \\
\text { expenditures }\end{array}$ & $\begin{array}{c}\text { Excluding } \\
\text { durables }\end{array}$ & $\begin{array}{c}\text { All } \\
\text { expenditures }\end{array}$ & $\begin{array}{c}\text { Excluding } \\
\text { durables }\end{array}$ \\
\hline $\begin{array}{l}\text { Round } 5 \\
\text { (Nov- } \\
\text { Dec, } \\
1994 \text { ) }\end{array}$ & 0.000 & 0.000 & 0.000 & 0.000 & 0.000 & 0.000 & 0.000 & 0.000 \\
\hline \multirow{3}{*}{$\begin{array}{l}\text { Round } 6 \\
\text { (Oct- } \\
\text { Nov, } \\
1995 \text { ) }\end{array}$} & 0.074 & 0.149 & & 0.122 & 0.039 & 0.127 & 0.089 & 0.131 \\
\hline & & & 0.079 & & & & & \\
\hline & $(0.118)$ & $(0.117)$ & $(0.088)$ & $(0.089)$ & $(0.118)$ & $(0.124)$ & $(0.065)$ & $(0.072)$ \\
\hline \multirow{2}{*}{$\begin{array}{l}\text { Round } 7 \\
\text { (Oct- } \\
\text { Nov, } \\
1996 \text { ) }\end{array}$} & 0.351 & 0.422 & 0.325 & 0.375 & 0.407 & 0.513 & 0.361 & 0.430 \\
\hline & $(0.061)$ & $(0.060)$ & $(0.049)$ & $(0.051)$ & $(0.110)$ & $(0.106)$ & $(0.074)$ & $(0.087)$ \\
\hline \multirow{2}{*}{$\begin{array}{l}\text { Round } 8 \\
\text { (Nov- } \\
\text { Dec, } \\
1998 \text { ) }\end{array}$} & 0.624 & 0.696 & 0.580 & 0.632 & 0.718 & 0.796 & 0.660 & 0.720 \\
\hline & $(0.046)$ & $(0.044)$ & $(0.038)$ & $(0.044)$ & $(0.089)$ & $(0.075)$ & $(0.067)$ & $(0.074)$ \\
\hline \multirow{2}{*}{$\begin{array}{l}\text { Round } 9 \\
\text { (Oct- } \\
\text { Nov, } \\
2000 \text { ) }\end{array}$} & 0.713 & 0.779 & 0.627 & 0.683 & 0.759 & 0.834 & 0.663 & 0.732 \\
\hline & $(0.041)$ & $(0.039)$ & $(0.058)$ & $(0.064)$ & $(0.109)$ & $(0.088)$ & $(0.098)$ & $(0.102)$ \\
\hline \multirow{2}{*}{$\begin{array}{l}\text { Round } \\
10 \text { (Oct- } \\
\text { Nov, } \\
2001)\end{array}$} & 0.735 & 0.795 & 0.637 & 0.689 & 0.802 & 0.866 & 0.686 & 0.755 \\
\hline & $(0.048)$ & $(0.043)$ & $(0.066)$ & $(0.071)$ & $(0.104)$ & $(0.083)$ & $(0.108)$ & $(0.110)$ \\
\hline $\begin{array}{l}\text { Average } \\
\text { bias per } \\
\text { month }\end{array}$ & $0.9 \%$ & $0.9 \%$ & $0.8 \%$ & $0.8 \%$ & $1.0 \%$ & $1.0 \%$ & $0.8 \%$ & $0.9 \%$ \\
\hline
\end{tabular}


Table 5a: Comparison of subjective evaluation of welfare change with change in real per capita expenditures, using the CPI as the deflator ${ }^{\mathrm{a}}$

\begin{tabular}{lrccccc}
\hline & \multicolumn{4}{l}{$\begin{array}{l}\text { Subjective welfare change } \\
\text { "How did you and your family live five years ago compared to now?" }\end{array}$} & \\
\cline { 2 - 6 } $\begin{array}{l}\text { Real per capita } \\
\text { expenditures in 1995: }\end{array}$ & $\begin{array}{c}\text { Much } \\
\text { better }\end{array}$ & $\begin{array}{c}\text { Somewhat } \\
\text { better }\end{array}$ & $\begin{array}{c}\text { Same as } \\
\text { now }\end{array}$ & $\begin{array}{c}\text { Somewhat } \\
\text { worse }\end{array}$ & $\begin{array}{c}\text { Much } \\
\text { worse }\end{array}$ & Total \\
\hline Higher than in 2000 & 973 & 1,411 & 1,398 & 458 & 183 & 4,423 \\
Lower than in 2000 & 376 & 643 & 834 & 332 & 125 & 2,310 \\
Total & 1,349 & 2,054 & 2,232 & 790 & 308 & 6,733 \\
\hline
\end{tabular}

${ }^{a}$ Cramer's $V=0.1009$; Chi-square $=68.5$ (significant at $p<0.0005$ ).

The CPI has a value of 485 in $2000(1995=100)$.

Table 5b: Comparison of subjective evaluation of welfare change with change in real per capita expenditures, using the bias-adjusted CPI as the deflator ${ }^{\mathrm{a}}$ Subjective welfare change "How did you and your family live five years ago compared to now?"

\begin{tabular}{lcccccc} 
Real per capita & Much & Somewhat & Same as & Somewhat & Much & \\
expenditures in 1995: & better & better & now & $\begin{array}{c}\text { Torse } \\
\text { worse }\end{array}$ & Total \\
\hline Higher than in 2000 & 889 & 1,282 & 1,233 & 390 & 153 & 4,023 \\
Lower than in 2000 & 460 & 772 & 999 & 400 & 155 & 2,710 \\
Total & 1,349 & 2,054 & 2,232 & 790 & 308 & 6,733 \\
\hline
\end{tabular}

${ }^{a}$ Cramer's $V=0.1158$; Chi-square $=90.2$ (significant at $p<0.00005$ ).

The bias-adjusted CPI has a value of 411 in $2000(1995=100)$. 
Table 6. The Effects of Own-Production of Potatoes

\begin{tabular}{|c|c|c|c|c|c|}
\hline & \multirow{2}{*}{$\begin{array}{l}\text { Proportion Consuming } \\
\text { from Own Production }\end{array}$} & \multirow{2}{*}{$\begin{array}{l}\text { Budget Share of Self- } \\
\text { Produced Potatoes }\end{array}$} & \multicolumn{2}{|c|}{ Cumulative Bias Estimates } \\
\hline & & & & $\begin{array}{l}\text { Excluding Own- } \\
\text { Production }\end{array}$ & $\begin{array}{l}\text { Including Own- } \\
\text { Production }^{\mathrm{a}}\end{array}$ \\
\hline $\begin{array}{l}\text { Round 5 } \\
\text { (Nov-Dec, } \\
1994 \text { ) }\end{array}$ & & 0.513 & 0.010 & 0.000 & 0.000 \\
\hline \multirow{2}{*}{$\begin{array}{l}\text { Round } \\
\text { (Oct-Nov, } \\
1995 \text { ) }\end{array}$} & 6 & 0.517 & 0.008 & 0.074 & 0.086 \\
\hline & & & & $(0.118)$ & $(0.112)$ \\
\hline \multirow{2}{*}{$\begin{array}{l}\text { Round } \\
\text { (Oct-Nov, } \\
\text { 1996) }\end{array}$} & 7 & 0.478 & 0.006 & 0.351 & 0.358 \\
\hline & & & & $(0.061)$ & $(0.058)$ \\
\hline \multirow{2}{*}{$\begin{array}{l}\text { Round } \\
\text { (Nov-Dec, } \\
1998 \text { ) }\end{array}$} & 8 & 0.470 & & 0.624 & 0.625 \\
\hline & & & & $(0.046)$ & $(0.045)$ \\
\hline \multirow{2}{*}{$\begin{array}{l}\text { Round } \\
\text { (Oct-Nov, } \\
2000)\end{array}$} & 9 & 0.461 & 0.005 & 0.713 & 0.712 \\
\hline & & & & $(0.041)$ & $(0.040)$ \\
\hline \multirow{2}{*}{$\begin{array}{l}\text { Round } \\
\text { (Oct-Nov, } \\
2001 \text { ) }\end{array}$} & 10 & 0.436 & 0.003 & 0.735 & 0.734 \\
\hline & & & & $(0.048)$ & $(0.046)$ \\
\hline
\end{tabular}

${ }^{a}$ Imputed values are derived by applying the average unit values for purchases to the production quantities reported by households.

Table 7. Budget Shares Before, During and After the 1998 Financial Crisis

\begin{tabular}{|c|c|c|c|c|c|}
\hline & Staple Food ${ }^{\mathrm{a}}$ & Non-Staple Food & All Food & Clothing & $\begin{array}{l}\text { Education, Health, } \\
\text { Recreation etc }\end{array}$ \\
\hline $\begin{array}{l}\text { Round } 7 \\
\text { Nov, 1996) }\end{array}$ & 0.225 & 0.320 & 0.545 & 0.083 & 0.082 \\
\hline $\begin{array}{l}\text { Round } 8 \\
\text { Dec, 1998) }\end{array}$ & 0.241 & 0.301 & 0.542 & 0.083 & 0.095 \\
\hline $\begin{array}{l}\text { Round 9 } \\
\text { Nov, 2000) }\end{array}$ & 0.204 & 0.290 & 0.494 & 0.104 & 0.093 \\
\hline $\begin{array}{l}\text { Average (1994 - } \\
\text { 2001) }\end{array}$ & 0.209 & 0.326 & 0.535 & 0.086 & 0.084 \\
\hline
\end{tabular}

${ }^{\mathrm{a}}$ Staple food includes white bread, black bread, macaroni products, rice/cereals, cabbage, potatoes, beets/carrots, onions/garlic, vegetable oil, flour, salt/spices, tea, milk, margarine and sugar. 
Appendix Table 1: Descriptive Statistics

\begin{tabular}{|c|c|c|c|c|c|c|c|c|c|}
\hline & \multicolumn{3}{|c|}{ Phase I } & \multicolumn{3}{|c|}{ Phase II } & \multicolumn{3}{|c|}{ Phase II Panel Sub-Sample } \\
\hline & $\begin{array}{c}\text { Mean }^{\mathrm{a}} \\
\text { (std. de } \\
\text { v) }\end{array}$ & $\begin{array}{l}\text { Round } 1 \\
\text { Mean }\end{array}$ & $\begin{array}{l}\text { Round } 4 \\
\text { Mean }\end{array}$ & $\begin{array}{l}\text { Mean }^{\mathrm{a}} \\
\text { (std. de } \\
\text { v) }\end{array}$ & $\begin{array}{l}\text { Round } 5 \\
\text { mean }\end{array}$ & $\begin{array}{c}\text { Round } \\
10 \\
\text { Mean }\end{array}$ & $\begin{array}{c}\text { Mean }^{\mathrm{a}} \\
\text { (std. de } \\
\text { v) }\end{array}$ & $\begin{array}{l}\text { Round } 5 \\
\text { Mean }\end{array}$ & $\begin{array}{l}\text { Round } \\
10 \\
\text { Mean }\end{array}$ \\
\hline $\begin{array}{l}\text { Budget share for food at } \\
\text { home }\end{array}$ & $\begin{array}{r}0.581 \\
(0.217)\end{array}$ & 0.581 & 0.561 & $\begin{array}{r}0.536 \\
(0.226)\end{array}$ & 0.565 & 0.475 & $\begin{array}{r}0.544 \\
(0.228)\end{array}$ & 0.566 & 0.487 \\
\hline $\ln$ (real total expenditure) & $\begin{array}{r}9.101 \\
(0.791)\end{array}$ & 9.119 & 9.071 & $\begin{array}{l}12.910 \\
(0.878)\end{array}$ & 13.116 & 12.970 & $\begin{array}{r}12.890 \\
(0.872)\end{array}$ & 13.118 & 12.858 \\
\hline 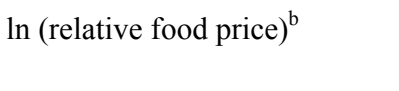 & n.a. & & & $\begin{array}{r}0.007 \\
(0.123)\end{array}$ & 0.060 & -0.036 & $\begin{array}{r}0.019 \\
(0.120)\end{array}$ & 0.060 & -0.013 \\
\hline $\ln$ (household size) & $\begin{array}{r}1.103 \\
(0.305)\end{array}$ & 1.115 & 1.101 & $\begin{array}{r}1.077 \\
(0.301)\end{array}$ & 1.081 & 1.074 & $\begin{array}{r}1.065 \\
(0.305)\end{array}$ & 1.088 & 1.028 \\
\hline$\%$ of household $\leq 2$ years old & $\begin{array}{r}0.021 \\
(0.077)\end{array}$ & 0.026 & 0.018 & $\begin{array}{r}0.019 \\
(0.073)\end{array}$ & 0.022 & 0.017 & $\begin{array}{r}0.016 \\
(0.067)\end{array}$ & 0.023 & 0.007 \\
\hline$\%$ of HH 3-14 year old boys & $\begin{array}{r}0.094 \\
(0.152)\end{array}$ & 0.094 & 0.093 & $\begin{array}{r}0.078 \\
(0.140)\end{array}$ & 0.083 & 0.068 & $\begin{array}{r}0.075 \\
(0.138)\end{array}$ & 0.085 & 0.056 \\
\hline$\%$ of $\mathrm{HH} 3-14$ year old girls & $\begin{array}{r}0.086 \\
(0.147)\end{array}$ & 0.090 & 0.085 & $\begin{array}{r}0.078 \\
(0.140)\end{array}$ & 0.087 & 0.063 & $\begin{array}{r}0.074 \\
(0.138)\end{array}$ & 0.088 & 0.050 \\
\hline$\%$ of $\mathrm{HH} 15-17$ year old boys & $\begin{array}{r}0.022 \\
(0.076)\end{array}$ & 0.022 & 0.024 & $\begin{array}{r}0.021 \\
(0.074)\end{array}$ & 0.021 & 0.022 & $\begin{array}{r}0.022 \\
(0.076)\end{array}$ & 0.021 & 0.026 \\
\hline$\%$ of $\mathrm{HH} 15-17$ year old girls & $\begin{array}{r}0.023 \\
(0.077)\end{array}$ & 0.023 & 0.022 & $\begin{array}{r}0.021 \\
(0.075)\end{array}$ & 0.017 & 0.025 & $\begin{array}{r}0.021 \\
(0.075)\end{array}$ & 0.018 & 0.028 \\
\hline Dummy: detached dwelling & n.a. & & & $\begin{array}{r}0.089 \\
(0.284)\end{array}$ & 0.081 & 0.092 & $\begin{array}{r}0.097 \\
(0.296)\end{array}$ & 0.079 & 0.126 \\
\hline Age of household head & $\begin{array}{r}45.186 \\
(11.686)\end{array}$ & 44.598 & 45.698 & $\begin{array}{r}45.886 \\
(12.212)\end{array}$ & 44.689 & 47.301 & $\begin{array}{r}47.003 \\
(12.077)\end{array}$ & 44.541 & 50.382 \\
\hline Age of spouse & $\begin{array}{r}42.783 \\
(12.618)\end{array}$ & 42.134 & 43.320 & $\begin{array}{r}43.649 \\
(13.345)\end{array}$ & 42.379 & 45.076 & $\begin{array}{r}44.881 \\
(13.276)\end{array}$ & 42.225 & 48.440 \\
\hline Head has tertiary education & $\begin{array}{r}0.245 \\
(0.430)\end{array}$ & 0.287 & 0.216 & $\begin{array}{r}0.264 \\
(0.441)\end{array}$ & 0.236 & 0.286 & $\begin{array}{r}0.248 \\
(0.432)\end{array}$ & 0.235 & 0.249 \\
\hline Spouse has tertiary education & $\begin{array}{r}0.230 \\
(0.421)\end{array}$ & 0.271 & 0.199 & $\begin{array}{r}0.278 \\
(0.481)\end{array}$ & 0.269 & 0.283 & $\begin{array}{r}0.272 \\
(0.445)\end{array}$ & 0.267 & 0.254 \\
\hline Head is working & $\begin{array}{r}0.715 \\
(0.452)\end{array}$ & 0.764 & 0.678 & $\begin{array}{r}0.669 \\
(0.470)\end{array}$ & 0.684 & 0.687 & $\begin{array}{r}0.654 \\
(0.476)\end{array}$ & 0.688 & 0.647 \\
\hline Spouse is working & $\begin{array}{r}0.694 \\
(0.461)\end{array}$ & 0.725 & 0.670 & $\begin{array}{r}0.652 \\
(0.476)\end{array}$ & 0.652 & 0.681 & $\begin{array}{r}0.658 \\
(0.474)\end{array}$ & 0.652 & 0.684 \\
\hline $\begin{array}{l}\% \text { of budget on food out of } \\
\text { home }\end{array}$ & $\begin{array}{r}0.025 \\
(0.066)\end{array}$ & 0.030 & 0.022 & $\begin{array}{r}0.041 \\
(0.086)\end{array}$ & 0.046 & 0.041 & $\begin{array}{r}0.038 \\
(0.084)\end{array}$ & 0.046 & 0.035 \\
\hline
\end{tabular}




\begin{tabular}{|c|c|c|c|}
\hline Round 2 (Jan-Mar, 1993) & $\begin{array}{r}0.240 \\
(0.427)\end{array}$ & n.a. & n.a. \\
\hline Round 3 (June-July, 1993) & $\begin{array}{r}0.243 \\
(0.429)\end{array}$ & n.a. & n.a. \\
\hline Round 4 (Oct 1993-Jan 1994) & $\begin{array}{r}0.242 \\
(0.428)\end{array}$ & n.a. & n.a. \\
\hline Round 6 (Oct-Nov, 1995) & n.a. & $\begin{array}{r}0.184 \\
(0.387)\end{array}$ & $\begin{array}{r}0.192 \\
(0.394)\end{array}$ \\
\hline Round 7 (Oct-Nov, 1996) & n.a. & $\begin{array}{r}0.169 \\
(0.375)\end{array}$ & $\begin{array}{r}0.165 \\
(0.371)\end{array}$ \\
\hline Round 8 (Nov-Dec, 1998) & n.a. & $\begin{array}{r}0.154 \\
(0.361)\end{array}$ & $\begin{array}{r}0.143 \\
(0.350)\end{array}$ \\
\hline Round 9 (Oct-Nov, 2000) & n.a. & $\begin{array}{r}0.145 \\
(0.352)\end{array}$ & $\begin{array}{r}0.134 \\
(0.341)\end{array}$ \\
\hline Round 10 (Oct-Nov, 2001) & n.a. & $\begin{array}{r}0.148 \\
(0.355)\end{array}$ & $\begin{array}{r}0.122 \\
(0.327)\end{array}$ \\
\hline Sample size & 8416 & 7753 & 6120 \\
\hline
\end{tabular}

Note:

The various expenditure definitions affect the dependent variable (food-at-home budget share), and ln (real total expenditure) and food-away-from-home share.

${ }^{\text {a }}$ For the expenditure and food share variables, the descriptive statistics are for "all expenditures" definition.

${ }^{\mathrm{b}}$ In terms of inflation rates rather than price levels. 
Appendix Table 2A. Sensitivity of Key Coefficients to Changes in Model Specification: Phase II RLMS

\begin{tabular}{|c|c|c|c|c|c|c|c|c|}
\hline & \multicolumn{4}{|c|}{ Excluding Regional Effects ${ }^{\mathrm{a}}$} & \multicolumn{4}{|c|}{ Using Quadratic Expenditures } \\
\hline & \multicolumn{2}{|c|}{ OLS Estimates } & \multicolumn{2}{|c|}{ IV Estimates $^{\mathrm{b}}$} & \multicolumn{2}{|c|}{ OLS Estimates } & \multicolumn{2}{|c|}{ IV Estimates $^{\mathrm{b}}$} \\
\hline & $\begin{array}{c}\text { All } \\
\text { expenditure } \\
\text { s }\end{array}$ & $\begin{array}{l}\text { Excluding } \\
\text { durables }\end{array}$ & $\begin{array}{c}\text { All } \\
\text { expenditur } \\
\text { es }\end{array}$ & $\begin{array}{l}\text { Excluding } \\
\text { durables }\end{array}$ & $\begin{array}{c}\text { All } \\
\text { expenditur } \\
\text { es }\end{array}$ & $\begin{array}{l}\text { Excluding } \\
\text { durables }\end{array}$ & $\begin{array}{c}\text { All } \\
\text { expenditur } \\
\text { es }\end{array}$ & $\begin{array}{c}\text { Excluding } \\
\text { durables }\end{array}$ \\
\hline $\begin{array}{l}\ln \text { (real total } \\
\text { expenditure }\end{array}$ & -0.079 & -0.071 & -0.102 & -0.093 & 0.750 & 0.805 & 0.390 & 0.442 \\
\hline ) & $(13.19)^{* *}$ & $(12.09)^{* *}$ & $(6.17)^{* *}$ & $(5.61)^{* *}$ & $(8.33)^{* *}$ & $(8.52)^{* *}$ & $(0.95)$ & $(1.06)$ \\
\hline $\begin{array}{l}\text { [ln real total } \\
\text { expenditure } \\
]^{2}\end{array}$ & & & & & -0.032 & -0.034 & -0.019 & -0.021 \\
\hline $\begin{array}{l}\text { Time } \\
\text { dummy } \\
\text { variables }\end{array}$ & & & & & & & & \\
\hline $\begin{array}{l}\text { Round } 6 \\
\text { (Oct-Nov, } \\
1995 \text { ) }\end{array}$ & -0.007 & -0.012 & -0.009 & -0.013 & -0.008 & -0.012 & -0.009 & -0.013 \\
\hline & $(0.64)$ & $(1.17)$ & $(0.80)$ & $(1.22)$ & $(0.72)$ & $(1.22)$ & $(0.85)$ & $(1.24)$ \\
\hline Round & -0.039 & -0.043 & -0.047 & -0.049 & -0.039 & -0.043 & -0.047 & -0.049 \\
\hline & $(3.95)^{* *}$ & $(4.17)^{* *}$ & $(4.50)^{* *}$ & $(4.58)^{* *}$ & $(4.19)^{* *}$ & $(4.38)^{* *}$ & $(4.55)^{* *}$ & $(4.62)^{* *}$ \\
\hline Round 8 & -0.082 & -0.089 & -0.096 & -0.101 & -0.074 & -0.081 & -0.092 & -0.097 \\
\hline & $(7.93)^{* *}$ & $(8.62)^{* *}$ & $(7.12)^{* *}$ & $(7.77)^{* *}$ & $(7.43)^{* *}$ & $(8.06)^{* *}$ & $(6.34)^{* *}$ & $(6.78)^{* *}$ \\
\hline Round & -0.103 & -0.111 & -0.111 & -0.117 & -0.103 & -0.112 & -0.111 & -0.118 \\
\hline & $(10.00)^{* *}$ & $(10.44)^{* *}$ & $(11.23)^{* *}$ & $(11.57)^{* *}$ & $(10.12)^{* *}$ & $(10.63)^{* *}$ & $(11.28)^{* *}$ & $(11.69)^{* *}$ \\
\hline Round 10 & -0.112 & -0.118 & -0.117 & -0.122 & -0.114 & -0.119 & -0.118 & -0.123 \\
\hline & $(10.82)^{* *}$ & $(12.21)^{* *}$ & $(11.88)^{* *}$ & $(13.17)^{* *}$ & $(10.78)^{* *}$ & $(12.26)^{* *}$ & $(11.92)^{* *}$ & $(13.24)^{* *}$ \\
\hline$R^{2}$ & 0.246 & 0.234 & 0.242 & 0.230 & 0.277 & 0.268 & 0.267 & 0.258 \\
\hline $\begin{array}{l}F \text {-test (time } \\
\text { dummies }=0 \\
\text { ) }\end{array}$ & $34.68^{* *}$ & $44.57 * *$ & $51.66^{* *}$ & $65.47 * *$ & $31.86 * *$ & $41.42 * *$ & $48.31 * *$ & $60.36^{* *}$ \\
\hline $\begin{array}{l}\text { Note: Absolut } \\
\text { significant at } \\
\text { Each model in } \\
\text { Round } 5 \text { (Nov } \\
\text { The various ex } \\
\text { food-away-fro } \\
{ }^{a} \text { Equation (10 }\end{array}$ & $\begin{array}{l}\text { alue of t-stat } \\
\text {; + significar } \\
\text { Ides backgro } \\
\text { ec, 1994). } \\
\text { nditure defin } \\
\text { home share. } \\
\text { here the tim }\end{array}$ & $\begin{array}{l}\text { tistics in parent } \\
\text { nt at } 10 \% \text {. } \\
\text { und coefficien } \\
\text { hitions affect th } \\
\text { e dummy varia }\end{array}$ & $\begin{array}{l}\text { theses correcte } \\
\text { ts and intercep } \\
\text { ne dependent v } \\
\text { ables capture th }\end{array}$ & $\begin{array}{l}\mathrm{d} \text { for cluster } \\
\text { ts that are no } \\
\text { ariable (fooc }\end{array}$ & $\begin{array}{l}\text { cts but not str } \\
\text { ported. The ex } \\
\text { home budget }\end{array}$ & $\begin{array}{l}\text { atification; } \\
\text { xcluded time } \\
\text { share), and } 1\end{array}$ & $\begin{array}{l}\text { gnificant at } \\
\text { mmy varia } \\
\text { eal total ex } \\
\text { rate for fo }\end{array}$ & $\begin{array}{l}\% ; * \\
\text { is for } \\
\text { relative to }\end{array}$ \\
\hline
\end{tabular}


Appendix Table 2B. Sensitivity of Key Coefficients to Changes in Model and Sample Specification: Phase II RLMS

\begin{tabular}{|c|c|c|c|c|c|c|c|c|}
\hline & \multicolumn{4}{|c|}{ Ignoring Sampling Weights } & \multicolumn{4}{|c|}{$\begin{array}{l}\text { Using All Households Rather Than Just Two- } \\
\text { Adult Households }{ }^{\mathrm{a}}\end{array}$} \\
\hline & \multicolumn{2}{|c|}{ OLS Estimates } & \multicolumn{2}{|c|}{ IV Estimates ${ }^{\mathrm{b}}$} & \multicolumn{2}{|c|}{ OLS Estimates } & \multicolumn{2}{|c|}{ IV Estimates $^{\mathrm{b}}$} \\
\hline & $\begin{array}{c}\text { All } \\
\text { expenditur } \\
\text { es }\end{array}$ & $\begin{array}{l}\text { Excluding } \\
\text { durables }\end{array}$ & $\begin{array}{c}\text { All } \\
\text { expenditur } \\
\text { es }\end{array}$ & $\begin{array}{l}\text { Excluding } \\
\text { durables }\end{array}$ & $\begin{array}{c}\text { All } \\
\text { expenditur } \\
\text { es }\end{array}$ & $\begin{array}{l}\text { Excluding } \\
\text { durables }\end{array}$ & $\begin{array}{c}\text { All } \\
\text { expenditur } \\
\text { es }\end{array}$ & $\begin{array}{l}\text { Excluding } \\
\text { durables }\end{array}$ \\
\hline $\ln$ (real & -0.080 & -0.072 & -0.103 & -0.093 & -0.082 & -0.073 & -0.121 & -0.112 \\
\hline & $(13.32)^{* *}$ & $(12.08)^{* *}$ & $(6.46)^{* *}$ & $(5.87)^{* *}$ & $(11.49)^{* *}$ & $(10.34)^{* *}$ & $(9.45)^{* *}$ & $(8.33)^{* *}$ \\
\hline \multicolumn{9}{|l|}{$\begin{array}{l}\text { Time } \\
\text { dummy } \\
\text { variables }\end{array}$} \\
\hline \multirow{2}{*}{$\begin{array}{l}\text { Round } 6 \\
\text { (Oct-Nov, } \\
1995 \text { ) }\end{array}$} & -0.007 & -0.012 & -0.009 & -0.013 & -0.010 & -0.016 & -0.013 & -0.018 \\
\hline & $(0.63)$ & $(1.15)$ & $(0.79)$ & $(1.21)$ & $(1.09)$ & $(1.84)^{+}$ & $(1.44)$ & $(2.05)+$ \\
\hline \multirow{2}{*}{$\begin{array}{l}\text { Round } 7 \\
\text { (Oct-Nov, } \\
1996 \text { ) }\end{array}$} & -0.041 & -0.045 & -0.049 & -0.051 & -0.044 & -0.050 & -0.053 & -0.058 \\
\hline & $(4.19)^{* *}$ & $(4.38)^{* *}$ & $(4.81)^{* *}$ & $(4.85)^{* *}$ & $(6.57)^{* *}$ & $(7.39)^{* *}$ & $(6.82)^{* *}$ & $(7.60)^{* *}$ \\
\hline \multirow{2}{*}{$\begin{array}{l}\text { Round } 8 \\
\text { (Nov-Dec, } \\
1998 \text { ) }\end{array}$} & -0.084 & -0.090 & -0.097 & -0.102 & -0.091 & -0.099 & -0.113 & -0.119 \\
\hline & $(8.31)^{* *}$ & $(8.78)^{* *}$ & $(8.02)^{* *}$ & $(8.56)^{* *}$ & $(11.22) * *$ & $(12.26)^{* *}$ & $(10.85)^{* *}$ & $(12.13)^{* *}$ \\
\hline \multirow{2}{*}{$\begin{array}{l}\text { Round } 9 \\
\text { (Oct-Nov, } \\
2000 \text { ) }\end{array}$} & -0.105 & -0.112 & -0.112 & -0.118 & -0.109 & -0.116 & -0.121 & -0.126 \\
\hline & $(9.69)^{* *}$ & $(10.12)^{* *}$ & $(10.95)^{* *}$ & $(11.25)^{* *}$ & $(12.72)^{* *}$ & $(13.15)^{* *}$ & $(14.60)^{* *}$ & $(15.24)^{* *}$ \\
\hline \multirow{2}{*}{$\begin{array}{l}\text { Round } 10 \\
\text { (Oct-Nov, } \\
2001 \text { ) }\end{array}$} & -0.114 & -0.119 & -0.119 & -0.123 & -0.114 & -0.122 & -0.122 & -0.128 \\
\hline & $(11.09)^{* *}$ & $(12.14)^{* *}$ & $(12.14)^{* *}$ & $(13.08)^{* *}$ & $(13.16)^{* *}$ & $(15.91)^{* *}$ & $(14.55)^{* *}$ & $(17.41)^{* *}$ \\
\hline$R^{2}$ & 0.247 & 0.234 & 0.243 & 0.230 & 0.267 & 0.256 & 0.253 & 0.241 \\
\hline $\begin{array}{l}F \text {-test (time } \\
\text { dummies }=0 \\
\text { ) }\end{array}$ & $41.90 * *$ & $50.43 * *$ & $62.74 * *$ & $72.25^{* *}$ & $46.27 * *$ & $65.56^{* *}$ & $53.61 * *$ & $75.13^{* *}$ \\
\hline \multicolumn{9}{|c|}{$\begin{array}{l}\text { Note: Absolute value of t-statistics in parentheses corrected for cluster effects but not stratification; }{ }^{*} \text { significant at } 5 \% \text {; } * \\
\text { significant at } 1 \% \text {; + significant at } 10 \% \text {. } \\
\text { Each model includes background coefficients and intercepts that are not reported. The excluded time dummy variable is for } \\
\text { Round } 5 \text { (Nov-Dec, 1994). } \\
\text { The various expenditure definitions affect the dependent variable (food-at-home budget share), and ln (real total expenditure) and } \\
\text { food-away-from-home share. } \\
{ }^{a} \text { Dummy variables for couples with and without children, for mixed families and for non-family households are added to the } \\
\text { model (the excluded category is sole occupants). The sample size increases to } 10,466 \text { with the additional types of households } \\
\text { included. } \\
\text { b } \ln \text { (real total expenditure) is treated as the endogenous variable, with } \ln (\text { real total household income) as the instrument. }\end{array}$} \\
\hline
\end{tabular}


Appendix Table 2C. Sensitivity of Key Coefficients to Changes in Sample Specification: Phase II RLMS

\begin{tabular}{|c|c|c|c|c|c|c|c|c|}
\hline & \multicolumn{4}{|c|}{$\begin{array}{l}\text { Excluding Households With Food Shares Outside } \\
\qquad 0.02-0.90^{\mathrm{a}}\end{array}$} & \multicolumn{4}{|c|}{$\begin{array}{l}\text { Excluding Households With Monthly } \\
\text { Expenditures }<600 \text { Roubles }{ }^{\mathrm{b}}\end{array}$} \\
\hline & \multicolumn{2}{|c|}{ OLS Estimates } & \multicolumn{2}{|c|}{ IV Estimates $^{\mathrm{b}}$} & \multicolumn{2}{|c|}{ OLS Estimates } & \multicolumn{2}{|c|}{ IV Estimates $^{\mathrm{b}}$} \\
\hline & $\begin{array}{l}\text { All } \\
\text { expenditure } \\
\text { s }\end{array}$ & $\begin{array}{l}\text { Excluding } \\
\text { durables }\end{array}$ & $\begin{array}{c}\text { All } \\
\text { expenditure } \\
\mathrm{s}\end{array}$ & $\begin{array}{l}\text { Excluding } \\
\text { durables }\end{array}$ & $\begin{array}{c}\text { All } \\
\text { expenditure } \\
\text { s }\end{array}$ & $\begin{array}{l}\text { Excluding } \\
\text { durables }\end{array}$ & $\begin{array}{c}\text { All } \\
\text { expenditure } \\
\mathrm{s}\end{array}$ & $\begin{array}{l}\text { Excluding } \\
\text { durables }\end{array}$ \\
\hline \multirow{2}{*}{$\begin{array}{l}\ln (\text { real } \\
\text { total } \\
\text { expenditur } \\
\text { e) }\end{array}$} & -0.077 & -0.069 & -0.084 & -0.086 & -0.086 & -0.077 & -0.108 & -0.111 \\
\hline & $(13.17)^{* *}$ & $(12.07)^{* *}$ & $(6.34)^{* *}$ & $(6.21)^{* *}$ & $(14.26)^{* *}$ & $(12.97)^{* *}$ & $(6.11)^{* *}$ & $(5.97)^{* *}$ \\
\hline \multicolumn{9}{|l|}{$\begin{array}{l}\text { Time } \\
\text { dummy } \\
\text { variables }\end{array}$} \\
\hline \multirow{2}{*}{$\begin{array}{l}\text { Round } 6 \\
\text { (Oct-Nov, } \\
1995 \text { ) }\end{array}$} & -0.005 & -0.004 & -0.006 & -0.005 & -0.008 & -0.006 & -0.009 & -0.008 \\
\hline & $(0.51)$ & $(0.37)$ & $(0.58)$ & $(0.51)$ & $(0.71)$ & $(0.58)$ & $(0.85)$ & $(0.75)$ \\
\hline \multirow{2}{*}{$\begin{array}{l}\text { Round } 7 \\
\text { (Oct-Nov, } \\
\text { 1996) }\end{array}$} & -0.034 & -0.033 & -0.039 & -0.039 & -0.041 & -0.039 & -0.048 & -0.048 \\
\hline & $(3.61)^{* *}$ & $(3.38)^{* *}$ & $(4.01)^{* *}$ & $(4.00)^{* *}$ & $(4.18)^{* *}$ & $(3.93)^{* *}$ & $(4.63)^{* *}$ & $(4.62)^{* *}$ \\
\hline \multirow{2}{*}{$\begin{array}{l}\text { Round } 8 \\
\text { (Nov-Dec, } \\
\text { 1998) }\end{array}$} & -0.075 & -0.069 & -0.080 & -0.079 & -0.072 & -0.067 & -0.081 & -0.079 \\
\hline & $(8.17)^{* *}$ & $(7.38)^{* *}$ & $(7.20)^{* *}$ & $(7.08)^{* *}$ & $(6.78)^{* *}$ & $(6.23)^{* *}$ & $(6.45)^{* *}$ & $(6.33)^{* *}$ \\
\hline \multirow{2}{*}{$\begin{array}{l}\text { Round } 9 \\
\text { (Oct-Nov, } \\
2000)\end{array}$} & -0.090 & -0.086 & -0.093 & -0.092 & -0.104 & -0.100 & -0.110 & -0.109 \\
\hline & $(9.35)^{* *}$ & $(8.95)^{* *}$ & $(10.15)^{* *}$ & $(10.06)^{* *}$ & $(9.91)^{* *}$ & $(9.58)^{* *}$ & $(11.06)^{* *}$ & $(10.96)^{* *}$ \\
\hline \multirow{2}{*}{$\begin{array}{l}\text { Round } 10 \\
\text { (Oct-Nov, } \\
2001 \text { ) }\end{array}$} & -0.097 & -0.095 & -0.099 & -0.099 & -0.112 & -0.110 & -0.116 & -0.115 \\
\hline & $(9.56)^{* *}$ & $(9.31)^{* *}$ & $(10.57)^{* *}$ & $(10.26)^{* *}$ & $(10.75)^{* *}$ & $(10.53)^{* *}$ & $(11.74)^{* *}$ & $(11.37)^{* *}$ \\
\hline $\begin{array}{l}R^{2} \\
F \text {-test } \\
\text { (time } \\
\text { dummies= } \\
0 \text { ) }\end{array}$ & $\begin{array}{c}0.219 \\
27.97 * *\end{array}$ & $\begin{array}{c}0.204 \\
25.37^{* *}\end{array}$ & $\begin{array}{c}0.221 \\
40.91 * *\end{array}$ & $\begin{array}{c}0.203 \\
39.04 * *\end{array}$ & $\begin{array}{c}0.261 \\
32.58 * *\end{array}$ & $\begin{array}{c}0.246 \\
30.33^{* *}\end{array}$ & $\begin{array}{c}0.259 \\
47.04 * *\end{array}$ & $\begin{array}{c}0.236 \\
44.75^{* *}\end{array}$ \\
\hline \multicolumn{9}{|c|}{$\begin{array}{l}\text { Note: Absolute value of t-stat } \\
\text { significant at } 1 \% \text {; }+ \text { significar } \\
\text { Each model includes backgro } \\
\text { Round } 5 \text { (Nov-Dec, 1994). } \\
\text { The various expenditure defin } \\
\text { food-away-from-home share. } \\
\text { a Removes } 360 \text { observations. } \\
{ }^{b} \text { This is equivalent to US } \$ 22\end{array}$} \\
\hline
\end{tabular}




\section{DAVIDSON INSTITUTE WORKING PAPER SERIES - Most Recent Papers}

The entire Working Paper Series may be downloaded free of charge at: www.wdi.bus.umich.edu

CURRENT AS OF 5/04/04

\begin{tabular}{|c|c|c|}
\hline Publication & Authors & Date \\
\hline $\begin{array}{l}\text { No. 684: CPI Bias and Real Living Standards in Russia During the } \\
\text { Transition }\end{array}$ & $\begin{array}{l}\text { John Gibson, Steven Stillman and } \\
\text { Trinh Le }\end{array}$ & May 2004 \\
\hline $\begin{array}{l}\text { No. 683: Mission Implausible III: Measuring the Informal Sector in a } \\
\text { Transition Economy using Macro Methods }\end{array}$ & Jan Hanousek and Filip Palda & May 2004 \\
\hline $\begin{array}{l}\text { No. 682: The Other Side of the Moon: The Data Problem in Analyzing } \\
\text { Growth Determinants }\end{array}$ & $\begin{array}{l}\text { Jan Hanousek, Dana Hajkova and } \\
\text { Randall K. Filer }\end{array}$ & May 2004 \\
\hline $\begin{array}{l}\text { No. 681: Consumers' Opinion of Inflation Bias Due to Quality } \\
\text { Improvements }\end{array}$ & $\begin{array}{l}\text { Jan Hanousek and Randall K. } \\
\text { Filer }\end{array}$ & May 2004 \\
\hline $\begin{array}{l}\text { No. 680: IMF-Related Announcements, Fundamentals, and Creditor } \\
\text { Moral Hazard: A Case Study of Indonesia }\end{array}$ & $\begin{array}{l}\text { Ayşe Y. Evrensel and Ali M. } \\
\text { Kutan }\end{array}$ & May 2004 \\
\hline No. 679: Privatization Matters: Bank Efficiency in Transition Countries & $\begin{array}{l}\text { John P. Bonin, Iftekhar Hasan and } \\
\text { Paul Wachtel }\end{array}$ & Apr. 2004 \\
\hline $\begin{array}{l}\text { No. 678: Does Market Liberalisation Reduce Gender Discrimination? } \\
\text { Econometric Evidence from Hungary, 1986-1998 }\end{array}$ & $\begin{array}{l}\text { Dean Jolliffe and Nauro F. } \\
\text { Campos }\end{array}$ & Apr. 2004 \\
\hline $\begin{array}{l}\text { No. 677: Governance and Performance of Microfinance Institutions in } \\
\text { Central And Eastern Europe and the Newly Independent States }\end{array}$ & Valentina Hartarska & .2004 \\
\hline $\begin{array}{l}\text { No. 676: Equilibrium Exchange Rates in the Transition: The Tradable } \\
\text { Price-Based Real Appreciation and Estimation Uncertainty }\end{array}$ & $\begin{array}{l}\text { Balázs Égert and Kirsten } \\
\text { Lommatzsch }\end{array}$ & Apr. 2004 \\
\hline $\begin{array}{l}\text { No. 675: Productivity growth and the real appreciation of the accession } \\
\text { countries' currencies }\end{array}$ & $\begin{array}{l}\text { Kirsten Lommatzsch and Silke } \\
\text { Tober }\end{array}$ & Apr. 2004 \\
\hline $\begin{array}{l}\text { No. 674: Exchange Rate Policy and Inflation in Acceding Countries: } \\
\text { The Role of Pass-through }\end{array}$ & $\begin{array}{l}\text { Fabrizio Coricelli, Boštjan Jazbec } \\
\text { and Igor Masten }\end{array}$ & r. 2004 \\
\hline No. 673: Is Kazakhstan a Market Economy Yet? Getting warmer.... & Sharon Eicher & Apr. 2004 \\
\hline $\begin{array}{l}\text { No. 672: Financial Institutions and The Wealth of Nations: Tales of } \\
\text { Development }\end{array}$ & Jian Tong and $\mathrm{Cl}$ & Apr. 2004 \\
\hline $\begin{array}{l}\text { No. 671: Interest Rate Pass-Through in EU Acceding Countries: The } \\
\text { Case of the Czech Republic, Hungary and Poland }\end{array}$ & $\begin{array}{l}\text { esma, Balázs } \\
\text { Reininger }\end{array}$ & Mar. 2004 \\
\hline $\begin{array}{l}\text { No. 670: A minimum of rivalry: evidence from transition economies on } \\
\text { the importance of competition for innovation and growth }\end{array}$ & $\begin{array}{l}\text { Wendy Carlin, Mark Schaffer and } \\
\text { Paul Seabright }\end{array}$ & Mar. 2004 \\
\hline No. 669: Dual Track Liberalization: With and Without Losers & $\begin{array}{l}\text { Che and Giovanni } \\
\text { ni }\end{array}$ & Mar. 2004 \\
\hline $\begin{array}{l}\text { No. 668: Enterprise Restructuring and Firn } \\
\text { A Comparison of Rural and Urban Enterpr }\end{array}$ & $\begin{array}{l}\text { Xiao-yuan Dong, Louis } \\
\text { Putterman and Bulent Unel }\end{array}$ & Mar. 2004 \\
\hline $\begin{array}{l}\text { No. 667: A Tale of Two Provinces: The Institutional Environment and } \\
\text { Foreign Ownership in China }\end{array}$ & Yasheng Huang and Wenhua Di & Mar. 2004 \\
\hline $\begin{array}{l}\text { No. 666: Ownership Characteristics and Access to Finance: } \\
\text { Evidence from a Survey of Large Privatised Companies in Hungary } \\
\text { and Poland }\end{array}$ & $\begin{array}{l}\text { Natalia Isachenkova and Tomasz } \\
\text { Mickiewicz }\end{array}$ & Mar. 2004 \\
\hline $\begin{array}{l}\text { No. 665: Testing Creditor Moral Hazard in Sovereign Bond Markets: } \\
\text { A Unified Theoretical Approach and Empirical Evidence }\end{array}$ & $\begin{array}{l}\text { Ayşe Y. Evrensel and Ali M. } \\
\text { Kutan }\end{array}$ & Mar. 2004 \\
\hline $\begin{array}{l}\text { No. 664: Assessing Equilibrium Exchange Rates in CEE Acceding } \\
\text { Countries: Can We Have DEER with BEER without FEER? }\end{array}$ & Balázs Égert & Feb. 2004 \\
\hline $\begin{array}{l}\text { No. 663: Modelling stock returns in the G-7 and in selected CEE } \\
\text { economies: A non-linear GARCH approach }\end{array}$ & Balázs Égert and Yosra Koubaa & Feb. 2004 \\
\hline $\begin{array}{l}\text { No. 662: Institutional Change and Product Composition: Does the Initial } \\
\text { Quality of Institutions Matter? }\end{array}$ & $\begin{array}{l}\text { Johannes Moenius and Daniel } \\
\text { Berkowitz }\end{array}$ & Feb. 2004 \\
\hline No. 661: Dual track liberalization: With and without losers & $\begin{array}{l}\text { Jiahua Che and Giovanni } \\
\text { Facchini }\end{array}$ & Feb. 2004 \\
\hline $\begin{array}{l}\text { No. 660: Who Is in Favor of Enlargement? Determinants of Support for } \\
\text { EU Membership in the Candidate Countries' Referenda }\end{array}$ & Orla Doyle and Jan Fidrmuc & Feb. 2004 \\
\hline $\begin{array}{l}\text { No. 659: Creditor Moral Hazard in Equity Markets: } \\
\text { A Theoretical Framework and Evidence from Indonesia and K }\end{array}$ & $\begin{array}{l}\text { Ayşe Y. Evrensel and Ali M. } \\
\text { Kutan }\end{array}$ & Feb. 2004 \\
\hline
\end{tabular}

